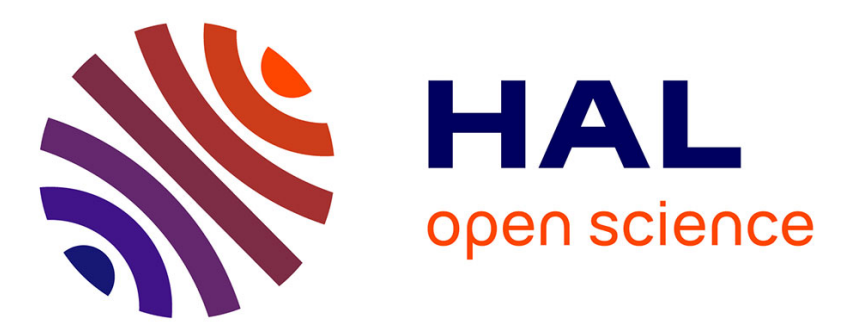

\title{
Operando Characterization and DFT Modeling of Nanospinels: Some Examples Showing the Relationship with Catalytic Activity
}

Frederik Tielens, Dominique Bazin

\section{- To cite this version:}

Frederik Tielens, Dominique Bazin. Operando Characterization and DFT Modeling of Nanospinels: Some Examples Showing the Relationship with Catalytic Activity. Applied Catalysis A: General, 2015, 504, pp.631-641. 10.1016/j.apcata.2015.01.049 . hal-01148442

\section{HAL Id: hal-01148442 https: / hal.sorbonne-universite.fr/hal-01148442}

Submitted on 4 May 2015

HAL is a multi-disciplinary open access archive for the deposit and dissemination of scientific research documents, whether they are published or not. The documents may come from teaching and research institutions in France or abroad, or from public or private research centers.
L'archive ouverte pluridisciplinaire $\mathbf{H A L}$, est destinée au dépôt et à la diffusion de documents scientifiques de niveau recherche, publiés ou non, émanant des établissements d'enseignement et de recherche français ou étrangers, des laboratoires publics ou privés. 


\title{
Operando Characterization and DFT Modeling of Nanospinels: Some Examples Showing the Relationship with Catalytic Activity
}

\author{
Frederik Tielens and Dominique Bazin*
}

CNRS, Sorbonne Université, UPMC Univ Paris 06, UMR 7574, Laboratoire Chimie de la Matière Condensée, Collège de France, 11 place Marcelin Berthelot, 75231 Paris Cedex 05, France

*Corresponding authors:

D. Bazin, e-mail: dominique.bazin@upmc.fr, tel.: +33 144276004, fax: +33144271507

\begin{abstract}
In this paper we have presented results on spinel nano-materials considering a collection of techniques, which is considered today a state-of the-art in the field of catalyst research (characterization and study of structure/reactivity relationship). Through a selected collection of techniques, experimental as well as theoretical, we illustrate this setup of techniques on the characterization of spinels $\left(\mathrm{ZnAl}_{2} \mathrm{O}_{4}\right)$ through XAS and by wide angle anomalous X-ray scattering (AWAXS). The effect of $\mathrm{Al} / \mathrm{Zn}$ substitution was investigated as well and related $\mathrm{Co} / \mathrm{Al}$ spinels were investigated on their catalytic properties using DFT. The catalytic properties towards $\mathrm{NO}, \mathrm{O}_{2}$, and $\mathrm{NH}_{3}$ are explored for the very first time on the $\mathrm{Co} / \mathrm{Al}$ spinel surfaces, and possible reaction mechanisms proposed.
\end{abstract}

Keywords: XA, AWAX, DFT, Spinels, Zn, Co, Al 


\section{Introduction}

As underlined by G. Ertl [1], it is after a report of J.W. Doebereiner regarding the reaction of hydrogen gas with oxygen on finely divided platinum powder that Berzelius defined this phenomenon as "catalysis", rather in order to introduce a classification than to offer a possible explanation. In fact, the definition of "catalysis" has been given by W. Ostwald [2,3]: "A catalyst is a substance which affects the rate of a chemical reaction without being part of its end products". A significant breakthrough has been then performed by 1912 Nobel prize winner Paul Sabatier [4] when he suggested the presence of more or less stable reaction intermediates. J.C. Vedrine [5,6] gives an elegant definition of the concept designated as "Sabatier principle". When a reactant is adsorbed on a catalyst surface, its energy of interaction should be strong enough for activation but not too strong to permit products to be desorbed (volcano curve of activity vs energy of adsorption). Such general explanation of catalytic phenomena based on the idea of the "temporary formation of unstable chemical compounds which, serving as intermediate steps in the reaction, determine its direction and increase its velocity".

Nowadays, many heterogeneous catalysts used in chemical industry consist of oxides. As underlined by J.C. Vedrine et al. [5,6], oxides are semiconductors or insulators and are used as active phases, as supports for active phases or even as both. Such catalysts exhibit redox properties (e.g. usually for transition metal ion oxides [7]), or acid-base properties (e.g. for $\mathrm{MgO}, \mathrm{SiO}_{2}-\mathrm{Al}_{2} \mathrm{O}_{3}$, zeolites [8]).

In order to describe catalytic reactions and active sites, a first step is given by a determination of the surface structure of the catalyst under reaction conditions. Such approach has to be completed by a fine description of the reaction mechanism, including the way the reactant molecules are adsorbed and activated. Numerous techniques, experimental and computational $[9,10]$, have been developed to depict at the atomic scale the surface structure of catalysts. For example, spin-echo mapping technique is a powerful technique for determining the oxidation state of $\mathrm{V}$ through the chemical shift of ${ }^{31} \mathrm{P}$ NMR peak [11]. The complete set of data shows clearly the complexity of transformations in VPO materials during preparation, activation and reaction, and leads to meaningful structure-activity relationships [12].

In this contribution, we would like as a first example to assess operando characterization of oxides through synchrotron radiation related techniques. For that purpose, we consider the $\mathrm{NO}$ decomposition process on nanospinels $\mathrm{ZnAl}_{2} \mathrm{O}_{4}$. As underlined by F. Garin [13], research 
on such catalytic reaction starts in the 1960s and corresponds to the emergence of the notion of the environment quality. We start this contribution by recalling some basic notions regarding the emissions of $\mathrm{CO}, \mathrm{HC}, \mathrm{NOx}$ and particulates caused by traffic emissions, then we will present the different catalytic systems which have used different very strict legislation appeared, reduce the nitric oxide concentration in exhaust gas typically averages 600-1200 ppm, depending on the engine combustion conditions, diesel or gasoline, and on the driving conditions. In the second part we present complementary computational results. In our group DFT studies have been conducted on a broad set of systems such as $\mathrm{MgO}$ [14], $\mathrm{SiO}_{2}$ [15-20], $\mathrm{TiO}_{2}$ [21-23 ], $\mathrm{V}_{2} \mathrm{O}_{5}$ [24], $\mathrm{CeO}_{2}[25], \mathrm{Al}_{2} \mathrm{O}_{3}$ [26], zeolites [27] etc. In this paper we present, results on spinels, on reactions related to the formation of nitric acid.

\section{Generalities}

Nowadays, significant characterization of catalysts made of nanoparticles is a reality [28-34]. Among the different techniques which can be used such as high-resolution transmission electron microscopy [35-37] or X-ray photoelectron spectroscopy [38], X-ray absorption spectroscopy (XAS) [39,40] using either soft (K edge of light elements as well as L edge of $3 \mathrm{~d}$ transition metals) $[41,42]$ or hard X-rays (K edge of $4 \mathrm{~d}$ transition metals as well as L edge of $5 \mathrm{~d}$ transition metals) [43,44] play a pivotal role not only in catalysis [45-51] but also in material science [52-58]. This is mainly due to the opportunity to combine at the very same time this technique specific to synchrotron radiation with other more classical spectroscopies such as Infrared [59,60], Raman [61,62], UV visible [63] spectroscopies or other techniques such as mass spectrometry with high time resolution [64]. Different breakthroughs have been also performed by combining XAS and X-Ray diffraction in heterogeneous catalysis [65-77] and more precisely on spinel [78]. Such approach allows the chemist to collect information on the catalytic reaction through the metal or the cations (through XAS) and through the molecules which interact at the surface of these nano-objects (through vibrational spectroscopies or through soft XAS [79]) at the very same time and on the very same catalyst. Note that such structural description is performed while the activity and selectivity of the reaction is measured $[80,81]$. Thanks to the different technological developments which have been performed on the optics and the detection, data acquisition can be done now at the milli $[82,83]$ or at the microsecond $[84,85]$ scale. Note that this technique has a major drawback, Exafs in unsensitiv to polydispersity $[86,87]$. 
From a fundamental point of view, some questions arise regarding the possibility to establish a significant relationship between the catalytic reaction (its activity and its selectivity) and the structural parameters which can be determined through XAS data. Regarding the kinetic, F. Thibault-Starzyk et al. [88] have pointed out that an acquisition time of milliseconds may not be relevant to explain the catalytic behaviour of a catalyst. Moreover, we have to underline that numerical simulations of XAS data is not easy when nano-objects are taking into account. We have already discussed the case of nanometer scale metallic particles $[89,90]$ and we will see in the next paragraph that the same difficulty exist for nanometer scale oxide particles. All these difficulties call for at the same time a critical discussion of the experimental data and a need to use theoretical tools. It is quite clear now that only such approach which combines experimental data coming from very different techniques collected while the chemical reaction occurs and theoretical simulations [91] using for example the DFT formalism will lead to a significant understanding of complex chemical reaction related to catalytic reactions.

\section{Characterization of Nanomaterials through XAS}

An elegant way to understand why special attention has to be paid to XAS data analysis of nanomaterials is given by the golden rule [92]. From theoretical considerations, W, the probability per unit time for a transition from an initial state $\mid \mathrm{i}>$ to a final state $\mid \mathrm{f}>$ by the action of a perturbation (here, it is an X-ray photon) is equal to $2 \pi h|<i| H|f>|^{2} \rho\left(E_{f}\right)$, where $\rho\left(E_{f}\right)$ is the density of final state. The fact that the density of state constitutes a physic parameter at the core of the peculiar properties of nanomaterial indicates clearly that special attention has to be paid on the data analysis procedure $[93,94]$.

In the case of nanometer scale metallic clusters [95-97], we have already shown that a strong correlation exists between the shape of the absorption edge [98] and the size of the cluster through ab initio calculation $[99,100]$. Thus, to explain the variations of the shape of white line intensity present at the absorption edge, it is not necessary to assume a charge transfer. Such properties exist also with oxide materials, and numerical simulations have been showed significant differences between simulations obtained for $\mathrm{CoO}$ bulk and ones corresponding to the $13 \mathrm{Co} 6 \mathrm{O}$ clusters [101].

The case of nanomaterials made of spinel such $\mathrm{ZnAl}_{2} \mathrm{O}_{4}[102,103]$ is even more exciting. The starting point is given by a comparison between the $\mathrm{Zn} \mathrm{K}$ and $\mathrm{L}_{\mathrm{III}}$ edge for the reference compound $\mathrm{ZnAl}_{2} \mathrm{O}_{4}$ (figure 1). This compound is associated to $\mathrm{Zn}^{2+}$ cations $\left(3 \mathrm{~d}^{10}\right.$ 
configuration). The strongest bonding effect in this $3 \mathrm{~d}$ oxide is due to the overlap between the oxygen $2 \mathrm{p}$ band (filled) and the $\mathrm{Zn} 4 \mathrm{~s}$ and $4 \mathrm{p}$ bands (empty) which forms the shape of the oxygen $2 \mathrm{p}$ valence band and also the $\mathrm{Zn} 4 \mathrm{~s}$ and $4 \mathrm{p}$ conduction band. From an experimental point of view, the similarity observed between the $\mathrm{K}$ and the $\mathrm{L}$ edge leads to the fact that some overlap exists between the conduction band (zinc $4 s$ and $4 p$ with oxygen $2 p$ ) and the $3 d$ band, creating very weak $3 d$ character following the same shape as the $4 p$ states.

The case of nanomaterials made of spinel such $\mathrm{ZnAl}_{2} \mathrm{O}_{4}[104]$ is even more exciting. The starting point is given by a comparison between the $\mathrm{Zn} \mathrm{K}$ and $\mathrm{L}_{\mathrm{III}}$ edge for the reference compound $\mathrm{ZnAl}_{2} \mathrm{O}_{4}$ (figure 1). This compound is associated to $\mathrm{Zn}^{2+}$ cations $\left(3 \mathrm{~d}^{10}\right.$ configuration). The strongest bonding effect in this $3 \mathrm{~d}$ oxide is due to the overlap between the oxygen $2 p$ band (filled) and the $\mathrm{Zn} 4 \mathrm{~s}$ and $4 \mathrm{p}$ bands (empty) which forms the shape of the oxygen $2 \mathrm{p}$ valence band and also the $\mathrm{Zn} 4 \mathrm{~s}$ and $4 \mathrm{p}$ conduction band. From an experimental point of view, the similarity observed between the $\mathrm{K}$ and the L edge leads to the fact that some overlap exists between the conduction band (zinc $4 s$ and $4 p$ with oxygen $2 p$ ) and the $3 d$ band, creating very weak $3 \mathrm{~d}$ character following the same shape as the $4 \mathrm{p}$ states.

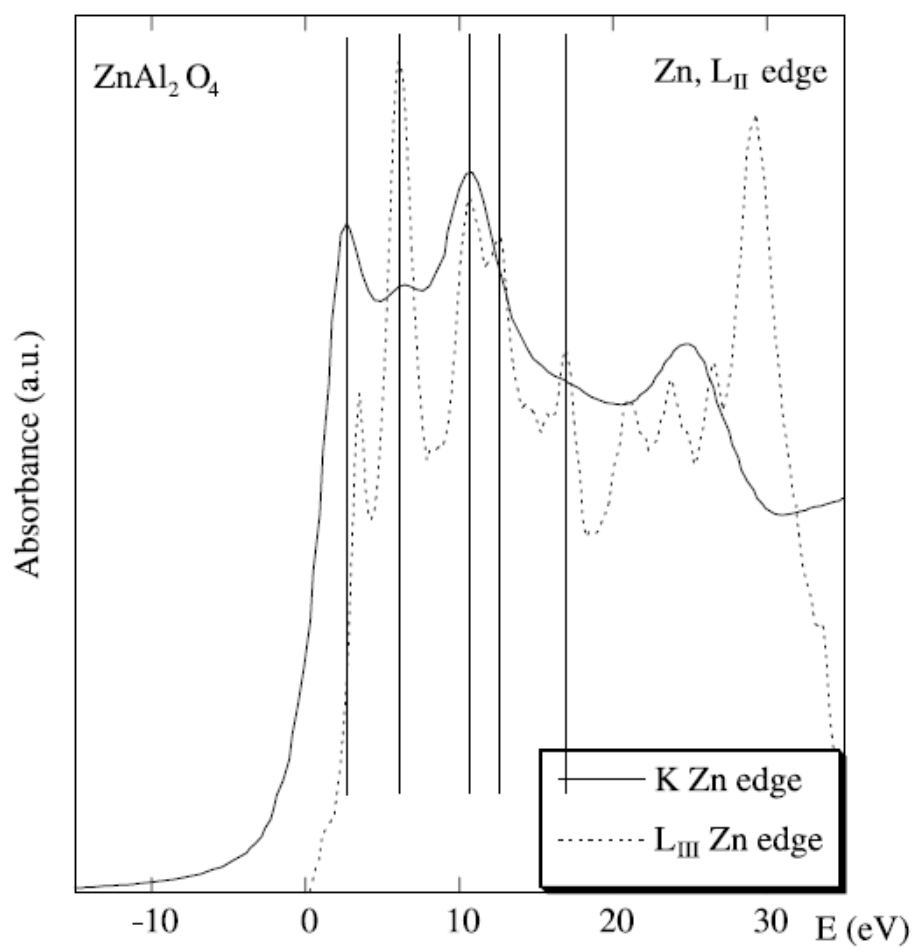

Figure 1. Comparison between the $\mathrm{Zn} \mathrm{K}$ and $\mathrm{L}_{\mathrm{III}}$ edge for the reference compound $\mathrm{ZnAl}_{2} \mathrm{O}_{4}$.

Regarding the study of nanomaterials, we have compared on figures 2 and 3 the near edge region of the model compound $\left(\mathrm{ZnAl}_{2} \mathrm{O}_{4}\right)$ and the supported catalytic system 
$\mathrm{ZnAl}_{2} \mathrm{O}_{4} / \gamma_{\mathrm{c}}-\mathrm{Al}_{2} \mathrm{O}_{3}$ for the $\mathrm{K}$ (figure 2) and $\mathrm{L}$ edge (figure 3). At first glance, regarding the shape as well as the position of the edge, a great similarity exists between the catalyst and the $\mathrm{ZnAl}_{2} \mathrm{O}_{4}$ spinel above the edge.

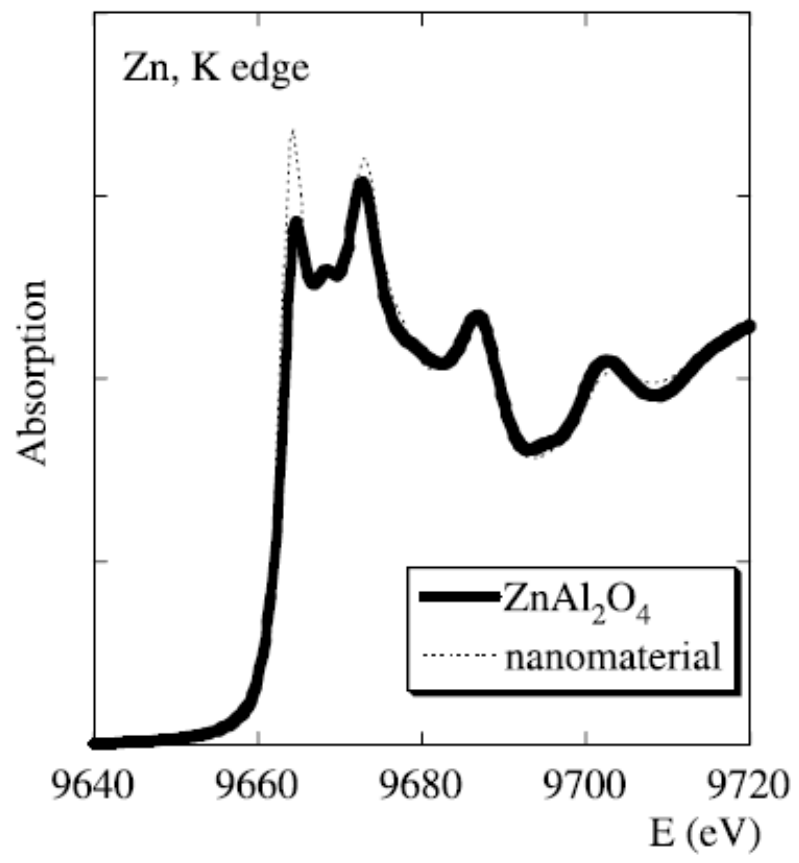

Figure 2. Near edge region at the $\mathrm{Zn} \mathrm{K}$ edge of the model compound $\mathrm{ZnAl}_{2} \mathrm{O}_{4}$ (line) compared with the near edge region associated with the catalyst (dots).

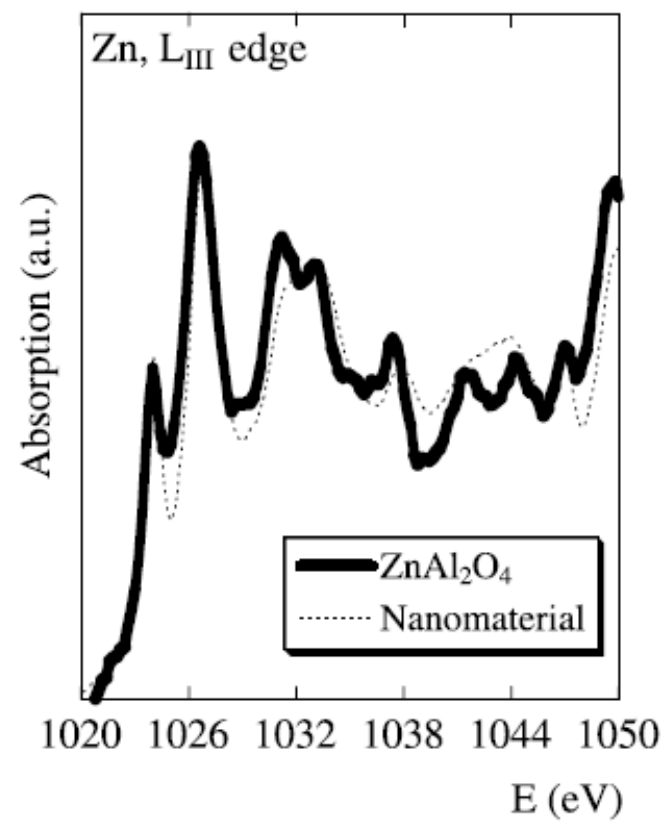

Figure 3. Near edge region at the $\mathrm{Zn} \mathrm{L}_{\mathrm{III}}$ edge of the model compound $\mathrm{ZnAl}_{2} \mathrm{O}_{4}$ (line) compared with the near edge region associated with the catalyst (dots). 
A careful analysis of the X-ray absorption spectra indicates that significant differences exist between the reference compound and the nanomaterial. At the K edge, the amplitude of the first peak of the catalyst is clearly lower than the one associated with the reference compound. At the L edge (Figure 3), even if each feature present at the edge exists, the amplitudes are significantly different between the two compounds. Numerical simulations using the code FeFF8MPI $[105,106]$ and a NERSC parallel machine with a cluster of 200 atoms were performed and quantitative agreements have been obtained. Such approach based on $\mathrm{K}$ and $\mathrm{L}$ edges have been also used in the case of Pd catalysts [107].

Regarding the literature dedicated to spinel compounds used as catalysts, numerous publications have been supported by XAS data [108-114]. Among them several are focused on Fischer-Tropsch synthesis for which the $\mathrm{Co} / \mathrm{Al}_{2} \mathrm{O}_{3}$ catalyst is the reference [115-119]. Indeed $\mathrm{Co}_{3} \mathrm{O}_{4}$ is a spinel structure, with one-third of the $\mathrm{Co}^{2+}$ occupying tetrahedral sites and two-thirds occupying octahedral sites and that $\mathrm{CoAl}_{2} \mathrm{O}_{4}$ is a normal spinel with $\mathrm{Co}^{2+}$ ions in tetrahedral sites. Improving the stability of such material constitutes an important challenge facing the commercial development of these catalysts for the conversion of coal, biomass, and natural gas to liquid fuels as alternative resources to crude oil.

Recently, G. Jacobs et al. [120] have assessed the use of synchrotron radiation techniques to confront issues associated with cobalt [121-125] and iron catalysts. These authors underlined that there has been an important spike in publications in the area of Fischer-Tropsch synthesis regarding the application of synchrotron radiation techniques which appear as major tools in catalysis. Among the different breakthroughs which have been done, these authors quote the manner in which cobalt catalysts reduces (i.e., a two-step reduction process by way of $\mathrm{Co}_{3} \mathrm{O}_{4}, \mathrm{CoO}$, and $\mathrm{Co}^{0}$ ), the manner in which iron catalysts undergo carburization, the influence of promoters on cobalt reduction in hydrogen and iron oxide carburization and also the local atomic structure of common promoters in Co catalysts.

\section{Opportunities offer by wide angle anomalous X-ray scattering (AWAXS)}

Even for the $\mathrm{ZnAl}_{2} \mathrm{O}_{4}$ spinel systems which can be considered quite simple because only the $\mathrm{T}_{\mathrm{d}}$ geometry has to be considered for $\mathrm{Zn}^{2+}$ cations, different structural parameters have to be considered. For example, we have to assess the size and the morphology of $\mathrm{ZnAl}_{2} \mathrm{O}_{4}$ cluster, the $\mathrm{Al} / \mathrm{Zn}$ substitution $\left(\mathrm{Zn}_{1-\mathrm{x}} \mathrm{Al}_{\mathrm{x}}\right) \mathrm{T}_{\mathrm{d}}\left(\mathrm{Al}_{2}\right) \mathrm{O}_{\mathrm{h}} \mathrm{O}_{4}$ with $\mathrm{x}=0-0.9$ as well as the spatial distribution of $\mathrm{Zn}^{2+}$ cations inside the $\mathrm{ZnAl}_{2} \mathrm{O}_{4}$ nanocluster. As already discussed, 
these structural parameters can be difficult to assess through X-ray absorption spectroscopy due to the presence of multiple scattering processes of the photoelectron [126].

Different investigations have already been dedicated to heterogeneous catalysis [127130], AWAXS experiments being a more easy way to consider such structural parameters [131-138]. This technique is based on the energy dependence of the atomic scattering factor, $\mathrm{f}(\mathrm{k}, \mathrm{E})$, near an absorption edge. As a simplification, this parameter is expressed in electron units as $f(k, E)=f_{0}(k)+f^{\prime}(E)+$ if' $(E)$ where $k(k=4 \pi \sin \theta / \lambda)$ bisects the angle between the incident and scattered directions and also defines the scattering plane. $\mathrm{f}_{0}(\mathrm{k})$ (which has evaluated by Cromer and Mann [139]) is the energy independent part of $f(k, E)$ the amplitude of the radiation coherently scattered by a single atom while f'(E) and f''(E) (which have been calculated by S. Sasaki [140]) are respectively the real and imaginary energy dependent correction. The success of the AWAXS technique [141-143] comes its ability to estimate the scattering intensity of nanometer scale clusters though the Debye equation [144]. Assuming a random (powder) arrangement of the structure with respect to the incoming X-ray beam, the intensity of coherently scattered X-rays is given by:

$$
I(k, E)=\sum \sum_{i j} f_{i}(k, E) f_{j}(k, E) \sin \left(k R_{i j}\right) / k R_{i j}
$$

In this equation, $I(k, E)$ is the intensity from coherent scattering, the sums over $i$ and $j$ are over all the atoms, $R_{i j}$ being the distance between the atom $i$ and $j$ and $f_{i}$ and $f_{j}$ being the atomic scattering factors. Such Debye equation leads to figure 4 on which we have reported the set of calculations which allows us to estimate the variation in scattered intensities in the case of a $\mathrm{Al} / \mathrm{Zn}$ substitution. 


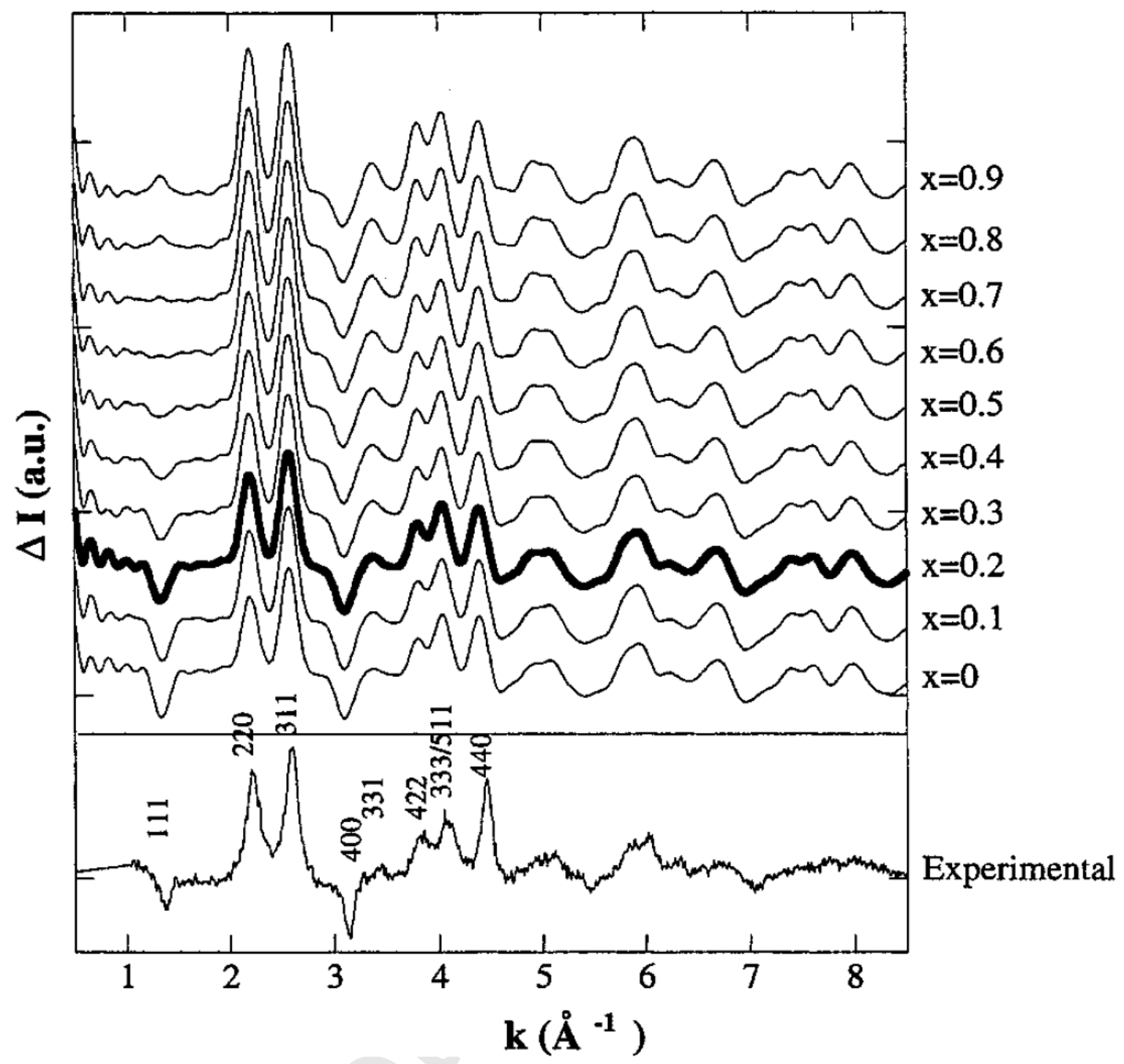

Figure 4. Numerical simulations based on a substitution $\mathrm{Al} / \mathrm{Zn}$ of $\left(\mathrm{Zn}_{1-\mathrm{x}} \mathrm{Al}_{\mathrm{x}}\right) \mathrm{T}_{\mathrm{d}}\left(\mathrm{Al}_{2}\right) \mathrm{O}_{\mathrm{h}} \mathrm{O}_{4}$ with $\mathrm{x}=0-0.9$.

As we can see on figure 4, the experimental results can be accurately reproduced for $\mathrm{x}$ $=0.2$, especially the features at (111), (220) and (311). The complete set of data collected on this catalytic system seems to describe a defective spinel structure in $\mathrm{Zn}^{2+}$ and $\mathrm{O}^{2-}$ around the zinc atoms and underline the importance of vacancies.

Now, thanks to the increase ability of beamtime on different synchrotron centres as well as the technical developments of optics and detection, such approach which combines XAS and AWAXS has been used to investigate different catalytic systems [132-138,145]. 


\section{Nitric Acid formation on CoAl spinels: a DFT study}

Nitric acid $\left(\mathrm{HNO}_{3}\right)$ is industrially produced by the stepwise catalytic oxidation of ammonia $\left(\mathrm{NH}_{3}\right)$ at high temperatures $\left(800-950^{\circ} \mathrm{C}\right)$ and pressures $(1-12$ bar) on platinum metal group (PGM) alloys. $\mathrm{NO}$ is first formed by the oxidation of $\mathrm{NH}_{3}$. High $\mathrm{NO}$ selectivities are obtained, however this technology presents two major drawbacks: formation of $\mathrm{N}_{2} \mathrm{O}$ as a byproduct and noble metal losses. Oxide-based catalysts represent an attractive alternative to noble metal alloys, due to a lower catalyst cost, the absence of expensive metal loss, and low $\mathrm{N}_{2} \mathrm{O}$ production. Co- and Fe-based spinel and perovskite catalysts are the most promising catalysts identified so far [146]. However, the lower NO yield achieved (promising systems give $85-90 \%$ as compared to $95 \%$ over PGM catalysts) makes difficult its industrial implementation. A detailed understanding of the reaction mechanism of ammonia oxidation over oxide-based catalysts may serve as a rational basis for an improved catalyst design. It involves studying not only the successive elementary steps of reaction between $\mathrm{NH}_{3}$ and $\mathrm{O}_{2}$, but also secondary processes, e.g. the interaction of unreacted $\mathrm{NH}_{3}$ with produced NO. In this way, activity and selectivity can be coupled.

We present results on the following points: Choice of bulk for the catalyst: Co/Al spinels $\left(\mathrm{Co}_{3} \mathrm{O}_{4}, \mathrm{Co}_{2} \mathrm{AlO}_{4}, \mathrm{CoAl}_{2} \mathrm{O}_{4}\right.$ and $\left.\mathrm{Al}_{3} \mathrm{O}_{4}\right)$ and the rock salt structure $\mathrm{CoO} . \mathrm{Co}_{3} \mathrm{O}_{4}$ is ranked as one of the most selective catalysts. $\mathrm{Co}_{2} \mathrm{AlO}_{4}$ has been chosen to represent the family of the spinels in the extensive investigation of the reaction (cation nature, oxidation state, and position). Choice of surfaces: after studying the stability of the low index surfaces: (100), (110), and (111), the most stable one (100) has been chosen for the adsorption studies. For $\mathrm{CoO}$ (rock salt structure), the choice of the (100) face is obvious.

\section{$\underline{\text { Computational details }}$}

Every geometry optimization (relaxation) and minimization of the total energy has been performed using the VASP code $[147,148]$. The energy calculated in VASP is the total energy, which is directly related to the thermodynamics, although at $0 \mathrm{~K}$. In the periodic DFT framework used, the Kohn-Sham equations have been solved by means of the generalized gradient approximation (GGA-PW91) proposed by Perdew and Wang [149,150]. High level calculations: For the calculation of the bulk, surfaces, and single adsorptions the plane-wave expansion was truncated at a cut-off energy of $400 \mathrm{eV}$. For the Brillouin-zone integration a $6 \times 6 \times 6$ Monkhorst-Pack special k-points grid has been used; the number of k-points has been 
adjusted to the size of the supercell considered in order to keep the same number of k-points in the reciprocal space.

Low level calculations: In the case of the coadsorption study the energy cut-off was lowered until $250 \mathrm{eV}$ and the Brillouin zone was integrated on a single k-point. This enabled us to calculate at a relative low calculation cost the different adsorption geometries of the reaction intermediates. The low level calculations were introduced in order to accelerate the calculations, since a relative large number of geometries (different adsorption combinations of the $\mathrm{N}_{\mathrm{x}} \mathrm{H}_{\mathrm{y}} \mathrm{O}$ species on the different adsorption sites, different possibilities for $\mathrm{NH}$ bond breaking and for H-transfer) have to be relaxed to obtain a reaction path. The size of the unit cells for the different models is in general rather large, leading to time-consuming calculations when the best accuracy is demanded.

We carefully checked the convergence of the energy with respect to the k-points. A spinunrestricted approach has been employed and the spin state has been optimized. A full optimization of atom positions, cell shape and volume has been performed via the action of a conjugate gradient optimization procedure.

A brief comparison of the two levels of calculation may be found looking at Table 2 and 3 . It shows that $\mathrm{E}_{\mathrm{ads}}\left(\mathrm{NH}_{3}\right)$ on $\mathrm{Co}_{2} \mathrm{AlO}_{4}$ is unaffected $(-0.86 \mathrm{eV}$ vs. $-0.85 \mathrm{eV})$, while that of $\mathrm{NO}$ is $\mathrm{E}_{\mathrm{ads}}(\mathrm{NO})$ is slightly decreased $(-2.12 \mathrm{eV}$ vs. $-2.56 \mathrm{eV})$. Their relative order is preserved.

\section{Thermodynamics of adsorption and co-adsorption involving the $\mathrm{NH}_{\mathrm{x}} \underline{\mathrm{O}}_{\mathrm{y}} \underline{\text { species }}$}

To our knowledge, the study of the surfaces and bulk of the $\mathrm{Co} / \mathrm{Al}$ spinels has not been published before. However, some theoretical studies using periodic DFT have already been published on related topics: adsorption of $\mathrm{CO}$ on $\mathrm{Co}_{3} \mathrm{O}_{4}$ spinel $[151,22]$ and reactivity of $\mathrm{Cu}_{2} \mathrm{AlO}_{4}$ towards ammonia[23].

Concerning the reaction paths, no studies on the adsorption of $\mathrm{NH}_{3}$ on oxides were found in literature, in particular none on a $\mathrm{Co} / \mathrm{Al}$ spinel type surface. An overview of the experimental and theoretical data when available can be found in [19].

\section{The topology and electronic structure surfaces}

For the bulk we have selected various spinels of different composition: $\left(\mathrm{Co}_{3} \mathrm{O}_{4}, \mathrm{Co}_{2} \mathrm{AlO}_{4}\right.$, $\mathrm{CoAl}_{2} \mathrm{O}_{4}$ and $\mathrm{Al}_{3} \mathrm{O}_{4}$ ) and rock salt $\mathrm{CoO}$. The first set (spinels) allows following the influence of the composition while preserving the structure. Cations are $\mathrm{Co}^{2+}, \mathrm{Co}^{3+}$ and $\mathrm{Al}^{3+}$. Relative to 
the $\mathrm{O}$ sublattice, $\mathrm{Co}^{2+}$ occupies the tetrahedral site while $\mathrm{Co}^{3+}$ and $\mathrm{Al}^{3+}$ are within the octahedral site. The different spinels considered were investigated on bulk and surface properties, allowing the study of the influence of the cations. The calculated lattice parameters are in agreement with known experimental determinations. The bulk of the most common mixed $\mathrm{Co} / \mathrm{Al}$ spinel $\mathrm{CoAl}_{2} \mathrm{O}_{4}$ was investigated in detail, geometrically as electronically.

For all the spinels studied, the most stable surface was found to be the (100) surface (see Table 1, annex), confirmed by experimental findings [24]. In the following, we assume that the adsorption take place on the terraces of this surface.

From the point of view of reactivity, it is interesting to note that the cation $T_{d}$ site (see fig 5 and 6) is pointing out of the (100) surface and is under coordinated (bridging 2 oxygen ions) while cation $\mathrm{O}_{\mathrm{h}}$ in the surface layer preserve a high coordination (five-fold). The surface oxygen is 4-fould coordinated.
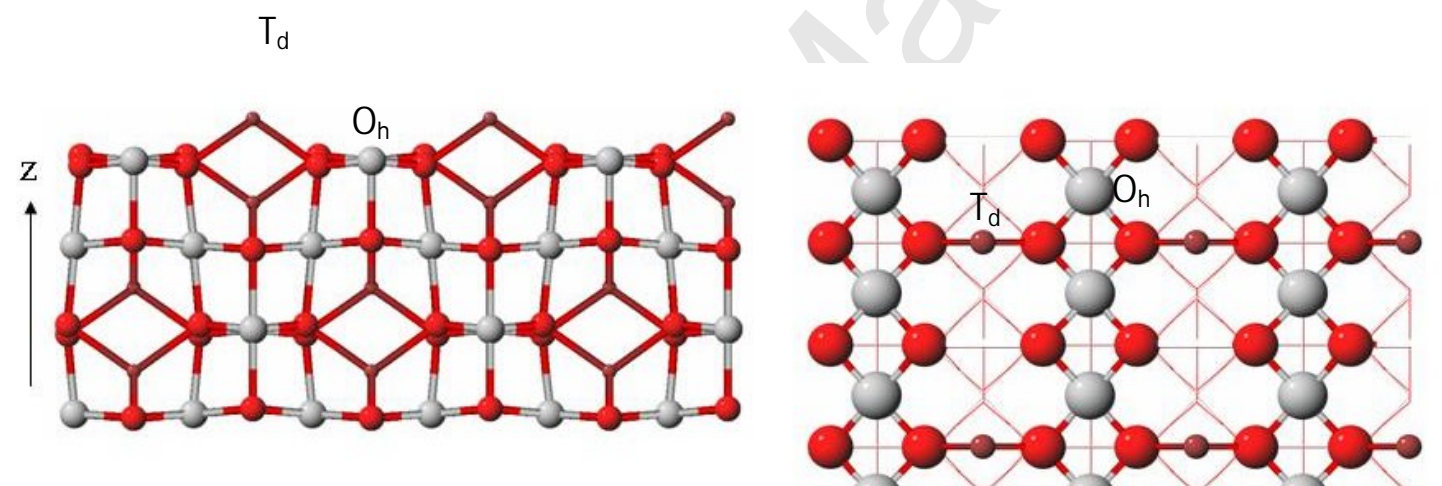
$\mathrm{Al}$ : grey
Co: dark red
$\mathrm{O}$ : red

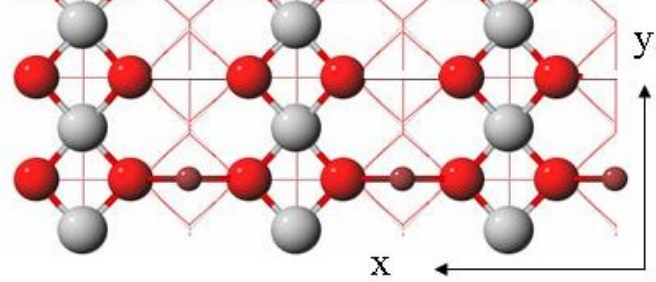

Figure 5: The (100) surface of the $\mathrm{CoAl}_{2} \mathrm{O}_{4}$ spinel.

Relaxation modifies the accessibility of the $T_{d}$ atom. In the case of the $\mathrm{Co}_{2} \mathrm{AlO}_{4}$ the $\mathrm{T}_{\mathrm{d}} \mathrm{Co}$ sinks into the surface, approaching the lower laying $T_{d}$ Co with the possible formation of a metal-metal bond; this property will have its significance in the adsorption behavior of the surface, and in particular towards molecular oxygen. On the contrary, for $\mathrm{CoAl}_{2} \mathrm{O}_{4}$, the $\mathrm{T}_{\mathrm{d}} \mathrm{Co}$

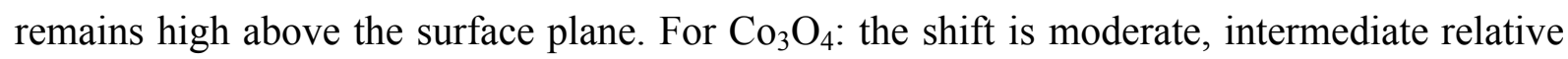
to those for the two other spinels. 

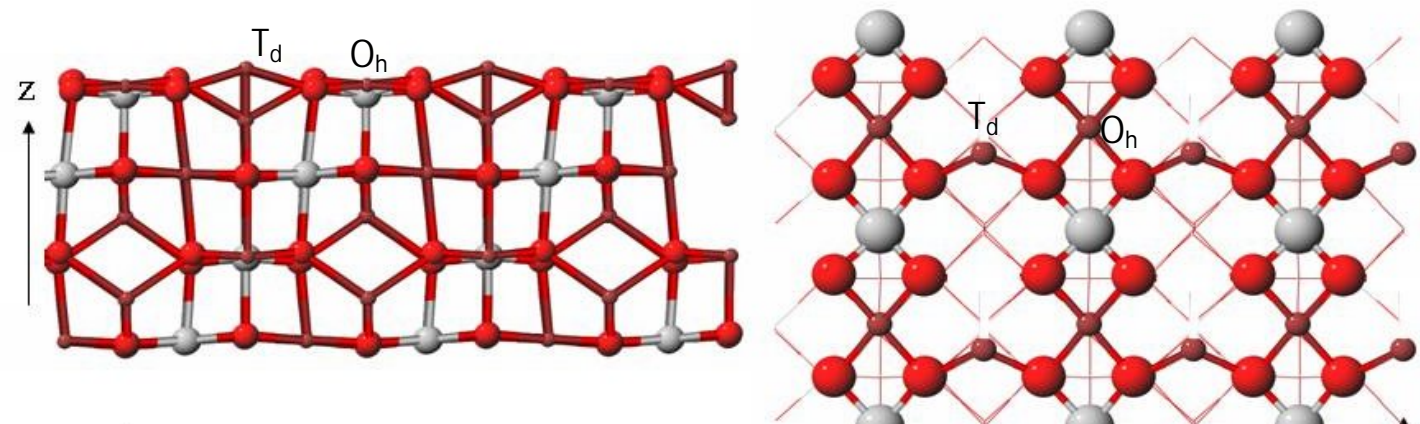
$\mathrm{Al}$ : grey
Co: dark red
$\mathrm{O}$ : red

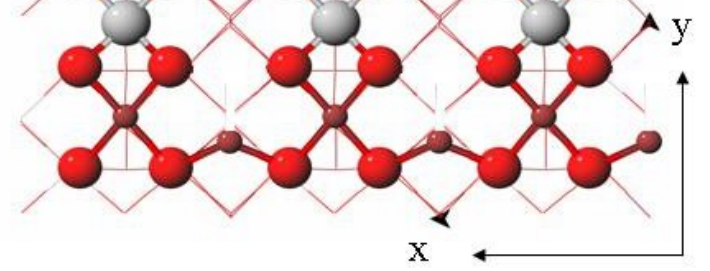

Figure 6: The (100) surface of the $\mathrm{Co}_{2} \mathrm{AlO}_{4}$ spinel. 
Table 1: Surface energies for the low index surfaces of $\mathrm{CoAl}_{2} \mathrm{O}_{4}$ spinel. Surface energies were calculated for the non-relaxed, atom positions 2 layer-relaxed in fixed volume, and full relaxation of volume and 2 layer atom positions of a 4 layer slab. In order to keep the stoichiometry 2 different surfaces were obtained (non-symmetric slab, here called upper and lower surface).

\begin{tabular}{|c|c|c|c|c|}
\hline Surface & Slab termination & $\mathrm{E}_{\text {surf }}\left(\mathrm{J} / \mathrm{m}^{2}\right)$ & $\mathrm{E}_{\text {surf }}\left(\mathrm{J} / \mathrm{m}^{2}\right)$ & $\mathrm{E}_{\text {surf }}\left(\mathrm{J} / \mathrm{m}^{2}\right)$ \\
\hline & & Non opt. & At. Pos. 2layers relax. & Vol. and at. pos. 2layers relax. \\
\hline 100 & $\begin{array}{l}1 \\
2 \\
2\end{array}$ & $\begin{array}{l}6.01 \\
2.44\end{array}$ & $\begin{array}{l}4.39 \\
1.93\end{array}$ & $\begin{array}{l}1.77 \text { (upper surf.) } \\
1.65 \text { (lower surf.) }\end{array}$ \\
\hline 110 & $\begin{array}{l}1 \\
2 \\
2\end{array}$ & $\begin{array}{l}3.28 \\
2.59\end{array}$ & $\begin{array}{l}3.26 \\
2.59\end{array}$ & $\begin{array}{l}3.12 \text { (upper surf.) } \\
3.16 \text { ( lower surf.) }\end{array}$ \\
\hline 111 & $\begin{array}{l}2 \\
3 \\
4\end{array}$ & $\begin{array}{l}4.79 \\
3.34 \\
6.45 \\
2.24\end{array}$ & $\begin{array}{l}4.86 \\
4.11 \\
3.95 \\
2.18\end{array}$ & 1.89 (upper surf.) \\
\hline
\end{tabular}

From the surface geometries the following can be observed: a) for the (100) surface of $\mathrm{CoAl}_{2} \mathrm{O}_{4}$, the Co $\mathrm{T}_{\mathrm{d}}$ are pointing out of the surface; $b$ ) for the $\mathrm{C}(100)$ surface of $\mathrm{Co}_{3} \mathrm{O}_{4}$, the accessibility of the Co $T_{d}$ is intermediate relative to the two other spinels; and c) the (100) surface of $\mathrm{Co}_{2} \mathrm{AlO}_{4}$ has the least accessible Co $\mathrm{T}_{\mathrm{d}}$. In other words for $\mathrm{CoAl}_{2} \mathrm{O}_{4}$ the $\mathrm{Co}_{\mathrm{d}}$ is more accessible for adsorption (in comparison with the other spinels). Note that a too high heat of adsorption of $\mathrm{O}_{2}$ (see Table 2) may also favor the conversion of $\mathrm{NH}_{3}$ to $\mathrm{N}_{2}$ and thus may have to be avoided. But to model the reaction $\mathrm{NH}_{3}+\mathrm{O}_{2}$ or $\mathrm{O}$ and $\mathrm{NH}_{3}+\mathrm{NO}$ we selected $\mathrm{Co}_{2} \mathrm{AlO}_{4}$ due to the unexpected lower activity toward $\mathrm{O}_{2}$ (vide ultra).

\section{The adsorption of reactants and products on the most stable surfaces}

We have focused on the interaction/adsorption of $\mathrm{NH}_{3}, \mathrm{O}_{2}$, and $\mathrm{NO}$ with the substrate, which should be present in the reaction. Different reaction mechanisms can be considered, considering co-adsorption of the reactants i.e. the so-called Langmuir Hinschelwood mechanism or the interaction of one of the reactants coming from the gas or liquid phase, so- 
called (Eley Rideal mechanism). At this stage we have chosen to investigate the former mechanism in which $\mathrm{NH}_{3}$, the reactant has to be adsorbed to react. The reaction is an oxidation and $\mathrm{O}_{2}$ is necessary. $\mathrm{NO}$ is the product and should either desorb, further oxidize or be reduced by ammonia forming side products. On the spinel compounds, the most reactive site is the $\mathrm{T}_{\mathrm{d}} \mathrm{Co}^{2+}$. The adsorption on the surface oxygen atoms is weak or does not occur. The ordering is $\mathrm{T}_{\mathrm{d}} \mathrm{Co}^{2+}>\mathrm{O}_{\mathrm{h}} \mathrm{Co}^{3+}>\mathrm{O}_{\mathrm{h}} \mathrm{Al}^{3+}>\mathrm{O}$ except for $\mathrm{NH}_{3}$ that is more strongly bounded to $\mathrm{Al}^{3+}$. Coordination is the driving force explaining the adsorption at the $\mathrm{T}_{\mathrm{d}} \mathrm{Co}^{2+}$ site.

$\mathrm{NH}_{3}$ and $\mathrm{NO}$ do not dissociate. Preliminary study on the $\mathrm{O}_{2}$ dissociation has been made; however this remains to be studied in more detail. The (100) surfaces have a higher affinity for $\mathrm{NO}$ than for $\mathrm{O}_{2}$ and $\mathrm{NH}_{3}$. The molecules are more strongly bound on $\mathrm{CoAl}_{2} \mathrm{O}_{4}$ than on $\mathrm{Co}_{3} \mathrm{O}_{4}$ followed by $\mathrm{Co}_{2} \mathrm{AlO}_{4}$ and $\mathrm{CoO}$.

The single adsorption of $\mathrm{NH}_{3}, \mathrm{O}_{2}$, and $\mathrm{NO}$ was calculated on a series of spinel-type oxides: $\mathrm{Co}_{3} \mathrm{O}_{4}, \mathrm{Co}_{2} \mathrm{AlO}_{4}$, and $\mathrm{CoAl}_{2} \mathrm{O}_{4}$, and the rock salt-type $\mathrm{CoO}$. The order of adsorption strengths $\left(\mathrm{CoAl}_{2} \mathrm{O}_{4}\right.$ stronger $\mathrm{Co}_{3} \mathrm{O}_{4}$ than, followed by $\mathrm{Co}_{2} \mathrm{AlO}_{4}$ and $\left.\mathrm{CoO}\right)$ is the same for all the adsorbates. The poor accessibility of the $\mathrm{Co} \mathrm{T}_{\mathrm{d}}$ site for $\mathrm{Co}_{2} \mathrm{AlO}_{4}$ explains that the heats of adsorption are weaker than for the other spinels. The electronegativity of the adjacent cations also contributes to explain this trend. The oxygen atoms bound to the $\mathrm{Co}^{2+}$ are less stabilizing when they are also engaged in strong bonds with other cations $\left(\mathrm{Al}^{3+}\right.$ more than $\mathrm{Co}^{3+}$ and much more than $\mathrm{Co}^{2+}$ ). 
Table 2: Calculated adsorption energies of $\mathrm{NH}_{3}, \mathrm{O}_{2}$ and $\mathrm{NO}$ on the different spinels, considered. (Values in eV)

\begin{tabular}{|c|c|c|c|c|c|c|c|c|c|c|c|c|}
\hline & \multicolumn{4}{|l|}{$\mathrm{NH}_{3}$} & \multicolumn{4}{|l|}{$\mathrm{O}_{2}$} & \multicolumn{4}{|l|}{$\mathrm{NO}$} \\
\hline & $\begin{array}{l}\mathrm{T}_{\mathrm{d}} \\
\mathrm{Co}^{2+}\end{array}$ & $\begin{array}{l}\mathrm{O}_{\mathrm{h}} \\
\mathrm{Co}^{3+}\end{array}$ & $\begin{array}{l}\mathrm{O}_{\mathrm{h}} \\
\mathrm{Al}^{3+}\end{array}$ & $\mathrm{O}^{2-}$ & $\begin{array}{l}\mathrm{T}_{\mathrm{d}} \\
\mathrm{Co}^{2+}\end{array}$ & $\begin{array}{l}\mathrm{O}_{\mathrm{h}} \\
\mathrm{Co}^{3+}\end{array}$ & $\begin{array}{l}\mathrm{O}_{\mathrm{h}} \\
\mathrm{Al}^{3+}\end{array}$ & $\mathrm{O}^{2-}$ & $\begin{array}{l}\mathrm{T}_{\mathrm{d}} \\
\mathrm{Co}^{2+}\end{array}$ & $\begin{array}{l}\mathrm{O}_{\mathrm{h}} \\
\mathrm{Co}^{3+}\end{array}$ & $\begin{array}{l}\mathrm{O}_{\mathrm{h}} \\
\mathrm{Al}^{3+}\end{array}$ & $\mathrm{O}^{2-}$ \\
\hline $\begin{array}{l}\mathrm{CoAl}_{2} \mathrm{O}_{4} \\
(100)\end{array}$ & -1.22 & - & -1.26 & -0.39 & -1.30 & - & -0.75 & - & -3.02 & - & -0.58 & No \\
\hline $\begin{array}{l}\mathrm{Co}_{3} \mathrm{O}_{4} \\
(100)\end{array}$ & -1.10 & -0.81 & - & - & -1.13 & -1.17 & - & & -2.73 & -1.71 & - & No \\
\hline $\begin{array}{l}\mathrm{Co}_{2} \mathrm{AlO}_{4} \\
(100)\end{array}$ & -0.85 & -0.26 & -0.58 & - & $-0.92^{*}$ & $-0.86^{*}$ & -0.40 & - & -2.56 & -1.57 & -0.13 & No \\
\hline $\begin{array}{l}\mathrm{CoO} \\
(100)\end{array}$ & -0.01 & - & - & - & -0.37 & 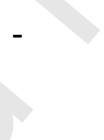 & - & - & -1.58 & - & - & - \\
\hline
\end{tabular}

* vertical adsorption (using lower level calculations, we have found other modes more stable; the values in this table are probably underestimated)

The crystals where the adsorption is calculated to be strong are those expected to be poorly reactive from experiment [25]. Since NO adsorption is the strongest, it might decrease the reactivity. It has been suggested [19] that there is an optimal range (window) for the adsorption strength of $\mathrm{O}_{2}$. It has been found that $\mathrm{CoO}$ is less selective for the production of NO. A too high heat of adsorption of $\mathrm{O}_{2}$ (see table 2) may favor the conversion of $\mathrm{NH}_{3}$ to $\mathrm{N}_{2}$ and thus should be avoided. The heat of adsorption of $\mathrm{O}_{2}$ is found too small on CoO. The validity of the lower level of calculation was tested in the case of $\mathrm{Co}_{2} \mathrm{AlO}_{4}$; the adsorption energies recalculated at a lower level where in qualitative agreement with those of high quality, even if the absolute numbers are slightly different, trends are similar. 
Table 3: Calculated adsorption energies of $\mathrm{NH}_{3}, \mathrm{O}_{2}$ and $\mathrm{NO}$ on $\mathrm{Co}_{2} \mathrm{AlO}_{4}$. (Values in $\mathrm{eV}$ )

\begin{tabular}{|l|llllllll|}
\hline & $\mathrm{NH}_{3}$ & $\mathrm{O}_{2}$ & $(\theta=1)$ & $\mathrm{O}_{2}(\theta=1 / 2)$ & $\mathrm{NO}$ & $\mathrm{N}_{2}$ & $\mathrm{H}_{2} \mathrm{O}$ & $\mathrm{H}$ \\
& & $\mathrm{mol}$ & diss & & & & \\
\hline Site & $\mathrm{T}_{\mathrm{d}}$ & $\mathrm{T}_{\mathrm{d}}-\mathrm{O}_{\mathrm{h}}$ & $\mathrm{T}_{\mathrm{d}}$ & $\mathrm{T}_{\mathrm{d}}$ & $\mathrm{T}_{\mathrm{d}}$ & $\mathrm{O}_{\mathrm{h}}$ & \\
& $\mathrm{Co}^{2+}$ & $\mathrm{Co}^{2+}-\mathrm{Co}^{3+}$ & $\mathrm{Co}^{2+}$ & $\mathrm{Co}^{2+}$ & $\mathrm{Co}^{2+}$ & $\mathrm{Co}^{3+}$ & $\mathrm{O}_{\text {surf }}$ \\
& & & & & & & & \\
\hline $\mathrm{Co}_{2} \mathrm{AlO}_{4}$ & -0.86 & -1.91 & -2.34 & -2.12 & -0.10 & -0.73 & -3.11 \\
& & & & & & & & \\
\hline
\end{tabular}

From Table 2 one can conclude that $\mathrm{NO}$ and $\mathrm{O}_{2}$ compete for the same adsorption site $\left(\mathrm{CoT}_{\mathrm{d}}\right)$. $\mathrm{O}_{2}$ seems to adsorb horizontally to the surface (side on), i.e. occupying both $\mathrm{T}_{\mathrm{d}}$ and $\mathrm{O}_{\mathrm{h}} \mathrm{Co}$ sites on the surface whereas $\mathrm{NO}$ does not. This means that $\mathrm{O}_{2}$ could easily saturate the surface before $\mathrm{NO}$ formation. Dissociation of $\mathrm{O}_{2}$ should be more investigated. The value of the oxygen heat of adsorption matches experimental findings. The experimental heat of adsorption for $\mathrm{O}_{2}$ on $\mathrm{CoO}$ is between $-0.4--1 \mathrm{eV}$, and $-1.7 \mathrm{eV}$ and $-2.7 \mathrm{eV}$ on $\mathrm{Co}_{3} \mathrm{O}_{4} \mathrm{~T}_{\mathrm{d}}$ and $\mathrm{O}_{\mathrm{h}}$ sites, respectively[19].

$\mathrm{Co}_{3} \mathrm{O}_{4}$ is selective, maybe as a consequence of a more appropriate value for the $\mathrm{O}_{2}$ adsorption. It is then important to carefully consider the heat of adsorption of $\mathrm{O}_{2}$ on the oxide surface (coverage and co-adsorption effects). From literature (experiment) it is found that a weak $\mathrm{O}_{2}$ binding makes the catalyst inactive, whereas a too strong $\mathrm{O}_{2}$ binding favors $\mathrm{N}_{2}$ production. The best surface should not adsorb $\mathrm{O}_{2}$ too strongly, but should be reactive enough to sufficiently adsorb $\mathrm{NH}_{3}$. The clue of the reaction is to find the optimum in $\mathrm{O}_{2}$ affinity with the catalyst surface.

The spinel with the optimum $\mathrm{O}_{2}$ heat of adsorption, due to the competition with $\mathrm{NO}$, is expected to be $\mathrm{Co}_{2} \mathrm{AlO}_{4}$. NO is found to chemisorb too energetically to the substrate and act as a poison to the catalyst (See Table 2). $\mathrm{CoO}$ is not appropriate since $\mathrm{O}_{2}$ poorly adsorbs and $\mathrm{NH}_{3}$ does not (or adsorbs very badly). Among the spinel structures, $\mathrm{Co}_{2} \mathrm{AlO}_{4}$ represents the case of smallest heats of adsorption. This result is in agreement with experimental observations [152]. 
It is not obvious that strong adsorption is necessary. A weak adsorption might be more promising for reactivity. The rate determining step might differ from the adsorption process. The effect of co-adsorption is studied in the next part. Finally, it should be recalled that for this study on the (100) surface, we have made the assumption that reactions occurred on terraces of the most stable surface. Steps, edges and other surfaces might be important favoring dissociation of adsorbates. In summary the adsorption mode of lowest energy correspond to the molecular adsorption (no dissociation). The adsorption trend: $\mathrm{NO}>\mathrm{O}_{2}>$ $\mathrm{NH}_{3}$ can be observed on all the surfaces studied. Concerning the adsorbates, the adsorption strengths decreases as following:

$$
\mathrm{CoAl}_{2} \mathrm{O}_{4}>\mathrm{Co}_{3} \mathrm{O}_{4}>\mathrm{Co}_{2} \mathrm{AlO}_{4}>\mathrm{CoO}
$$

It is interesting to note that $\mathrm{NH}_{3}$ does not dissociate on the surface (associative adsorption), and that the "surface oxygen" is poorly reactive, whereas the Co $\mathrm{Td}$ is the most reactive site. Considering only the oxygen atom already present on the naked surface and excluding adsorbed oxygen, therefore we also call them lattice oxygen. From these results it is obvious that $\mathrm{CoAl}_{2} \mathrm{O}_{4}$ and $\mathrm{Co}_{3} \mathrm{O}_{4}$ have too high adsorption energies; $\mathrm{NH}_{\mathrm{x}}$ species will reside too much time on the surface and react to $\mathrm{N}_{2} \cdot \mathrm{Co}_{2} \mathrm{AlO}_{4}$ is expected to be the best catalyst, having intermediate adsorption energies for $\mathrm{O}_{2}$ and weak for NO. The above mentioned spinels have the lowest $\mathrm{O}_{2}$ affinities of the spinels considered, however having a relative high affinity for $\mathrm{NH}_{3}$. CoO spinel is found to have a too low affinity for $\mathrm{O}_{2}$ and $\mathrm{NH}_{3}$. Concerning the adsorption, the behavior of the different spinels is expected to be comparable. Important here, is that the lattice oxygen does not participate in ammonia conversion and its oxidation to NO. Finally, the search for the optimal catalytic behavior (in practice) could not simply be related to the heats of adsorption of individual molecules. Here we have to make the hypothesis of a compromise between sufficient $\mathrm{NH}_{3}$ adsorption and relatively weak $\mathrm{O}_{2}$ adsorption which is the case of $\mathrm{Co}_{2} \mathrm{AlO}_{4}$.

\section{The co-adsorption of $\mathrm{NH}_{3}$ and $\mathrm{O}$ over $\mathrm{Co}_{2} \mathrm{AlO}_{4}$; formation of $\mathrm{NO}$}

The co-adsorption of $\mathrm{O}$ and $\mathrm{NH}_{3}$ has been studied by adding a single $\mathrm{O}$ atom to the unit cell; the adsorption is referred to $1 / 2 \mathrm{O}_{2}$. The results for $\mathrm{O}_{2}$ are presented in the next section they correspond to the undissociated form of $\mathrm{O}_{2}$. When the $\mathrm{O}$ atom is placed above a surface $\mathrm{O}$ atom (vertical), it moves without barrier to bind to the $\mathrm{CoT}_{\mathrm{d}}$. 
The co-adsorption energy of $1 / 2 \mathrm{O}_{2}$ and $\mathrm{NH}_{3}$ is $2.41 \mathrm{eV}$ while the sum of individual adsorption energies (table 3 ) represents $2.03 \mathrm{eV}$. The gain due to the coadsorption is $0.38 \mathrm{eV}$. We have not found a thermodynamically favored dissociation of $\mathrm{NH}_{3}$. The mode of lower energy found so far is represented in figure $7 \mathrm{~b}$. Both $\mathrm{OH}$ and $\mathrm{NH}_{2}$ are adsorbed on the $\mathrm{CoT}_{\mathrm{d}}$. It costs 0.27 $\mathrm{eV}$ relative to the undissociated form (figure 7a). We expect that the ammonia dehydrogenation is the rate-determining step in ammonia oxidation over cobalt spinels, however only the study of the transition state could be a proof. The $\mathrm{NH}_{3}-\mathrm{NO}$ coadsorption was done over $\mathrm{Co}_{2} \mathrm{Al}_{2} \mathrm{O}_{4}$. From some preliminary tests we expect no significant differences if going to $\mathrm{CoAlO}_{4}$ and $\mathrm{Co}_{3} \mathrm{O}_{4}$ systems.

a.

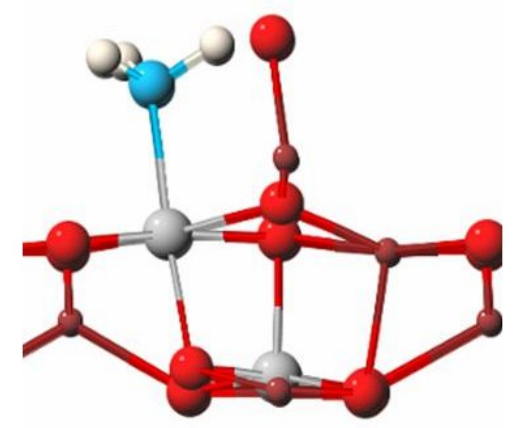

b.

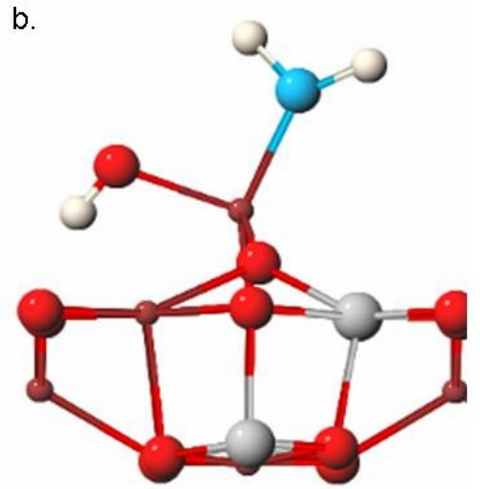

Figure 7: a. Best co-adsorption geometry found for the adsorption of atomic oxygen; the $\mathrm{O}$ atom is on the $\mathrm{CoT}_{\mathrm{d}}$. b. Best co-adsorption geometry found with $\mathrm{NH}_{3}$ cleavage.

Atomic $\mathrm{O}$ covers the most reactive cation $\mathrm{Co}^{2+} \mathrm{T}_{\mathrm{d}}$. There is a cooperative effect for $\mathrm{O}$ and $\mathrm{NH}_{3}$ co-adsorption. $\mathrm{NH}_{3}$ dissociation costs at least $\sim 0.3 \mathrm{eV}$ in the presence of $\mathrm{O}_{2}$

\section{The co-adsorption of $\mathrm{NH}_{3}$ and $\mathrm{O}_{2}$ over $\mathrm{Co}_{2} \mathrm{AlO}_{4}$ formation of $\mathrm{NO}$}

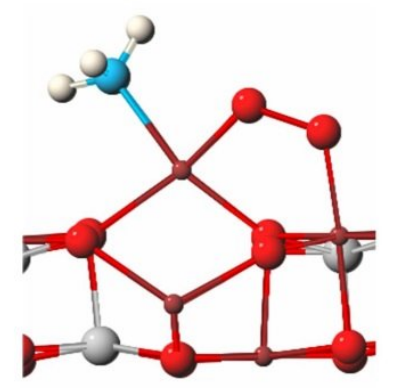

Figure 8: Best co-adsorption geometry found for the adsorption of $\mathrm{O}_{2}$ and $\mathrm{NH}_{3}$. 
The ammonia oxidation in the presence of adsorbed oxygen is expected to follow the resulting equations:

$$
\begin{aligned}
& 4 \mathrm{O}_{2}+2 \mathrm{NH}_{3} \rightarrow 2 \mathrm{HNO}_{3}+2 \mathrm{H}_{2} \mathrm{O} \\
& \text { Or } \\
& 5 \mathrm{O}_{2}+4 \mathrm{NH}_{3} \rightarrow 4 \mathrm{NO}+6 \mathrm{H}_{2} \mathrm{O}
\end{aligned}
$$

Thus, the study on the co-adsorption is a first step to consider a complete reactive system. Its thermodynamic evolution (not kinetics) was studied. Strong co-adsorption effects appear in our results, limited to $\mathrm{Co}_{2} \mathrm{AlO}_{4}$ and some preliminary test on other spinels. In other words, $\mathrm{NH}_{3}$ adsorbs better on an oxidized surface, in excess of $\mathrm{O}_{2}$. The adsorption site varies; $\mathrm{NH}_{3}$ adsorbs on $\mathrm{Al}^{3+}$ without oxygen; it is adsorbed on $\mathrm{Co}^{2+}$ when co-adsorbed. Note however that the cooperative effect remains even for less favorable adsorption modes. The co-adsorption energy of $\mathrm{O}_{2}$ and $\mathrm{NH}_{3}$ is $3.57 \mathrm{eV}$ while the sum of individual adsorption energies (table 3) represents $2.77 \mathrm{eV}$. The gain due to the coadsorption, $0.80 \mathrm{eV}$, is very large (obtained using low level calculations). In the best adsorption mode (figure 8) $\mathrm{O}_{2}$ does not dissociate but forms a peroxo compound bridging a $\mathrm{Co}^{2+}$ and an $\mathrm{Al}^{3+}$. The formation of peroxo that should be also expected to appear by atomic adsorption on stoichiometric surfaces was not found. The $\mathrm{NH}_{3}$ does not spontaneously dissociate, even in the presence of $\mathrm{O}_{2}$. Products of co-

\begin{tabular}{|c|c|c|c|c|c|}
\hline & $\mathrm{NH}_{3}+1 / 2 \mathrm{O}_{2}$ & $\begin{array}{l}\mathrm{NH}_{3}+\mathrm{O}_{2} \\
(\theta=1) \mathrm{mol}\end{array}$ & $\mathrm{NH}_{3}+\mathrm{NO}$ & $\mathrm{NH}_{3}+\mathrm{H}_{2} \mathrm{O}$ & $\mathrm{NO}+\mathrm{H}_{2} \mathrm{O}$ \\
\hline $\begin{array}{l}\text { Site for first } \\
\text { adsorbate }\end{array}$ & $\mathrm{Al}^{3+} \mathrm{O}_{\mathrm{h}}$ & $\mathrm{Co}^{2+} \mathrm{T}_{\mathrm{d}}$ & $\mathrm{Co}^{2+} \mathrm{T}_{\mathrm{d}}$ & $\mathrm{Co}^{2+} \mathrm{T}_{\mathrm{d}}$ & $\mathrm{Co}^{2+} \mathrm{T}_{\mathrm{d}}$ \\
\hline $\begin{array}{l}\text { Site for } \\
\text { second } \\
\text { adsorbate }\end{array}$ & $\mathrm{Co}^{2+} \mathrm{T}_{\mathrm{d}}$ & $\mathrm{Co}^{2+}-\mathrm{Co}^{3+}$ & $\mathrm{Co}^{2+} \mathrm{T}_{\mathrm{d}}$ & $\mathrm{Co}^{3+} \mathrm{O}_{\mathrm{h}}$ & $\mathrm{Co}^{3+} \mathrm{O}_{\mathrm{h}}$ \\
\hline $\mathrm{Co}_{2} \mathrm{AlO}_{4}$ & -2.41 & -3.57 & -2.02 & -1.29 & -2.51 \\
\hline $\begin{array}{l}\text { co-adsorp. } \\
\text { energy gain }\end{array}$ & -0.31 & -0.80 & +0.96 & +0.31 & +0.34 \\
\hline
\end{tabular}
adsorption are energy minima, and the $\mathrm{N}-\mathrm{H}$ cleavage is weakly endothermic.

Table 4: Co-adsorption energies and cooperative effect (Values in eV) 
In the following, we present various intermediates where $\mathrm{NH}_{3}$ dissociates. They correspond to reaction paths for the ammonia oxidation; successive $\mathrm{NH}_{\mathrm{x}} \mathrm{O}_{\mathrm{y}}$ intermediates are displayed in figure 9, the progression (from left hand-side to right hand-side) correspond to an increase of the number of $\mathrm{N}-\mathrm{H}$ bonds cleaved. Note that this scheme presents the thermodynamics (no transition states were computed); energy barriers are to be passed to go from one intermediate to the other.

From tests on $\mathrm{NH}_{3}$ dissociation on the (100) $\mathrm{CoAl}_{2} \mathrm{O}_{4}$ surface, i.e. a surface with a high $\mathrm{Al}$ content, similar cooperative effects were found: a gain for $\mathrm{NH}_{3}+\mathrm{O}_{2}$ and a loss for $\mathrm{NH}_{3}+\mathrm{NO}$ (Table 5). However, the effect is much more pronounced for the (100) $\mathrm{Co}_{2} \mathrm{AlO}_{4}$ surface. The energy values in Table 5 are obtained by making the difference between the adsorption energies of the individual molecular adsorptions and the co-adsorption. If the values are negative, co-adsorption is predicted to be more favorable than isolated adsorption, when positive values are obtained the opposite is true. The favorable co-operative effect (negative values) is thus due to the favorable balance between intermolecular interactions and steric hindering originating from the competition between the most favorable adsorption sites on the surface, which have to be shared between both competing molecules.

Table 5: cooperative effects for the co-adsorptions. (Values in eV)

\begin{tabular}{|c|cc|}
\hline & $(100) \mathrm{Co}_{2} \mathrm{AlO}_{4}$ surface & $(100) \mathrm{CoAl}_{2} \mathrm{O}_{4}$ surface \\
\hline $\mathrm{NH}_{3}+\mathrm{O}_{2}$ & -0.8 & -0.4 \\
$\mathrm{NH}_{3}+\mathrm{NO}$ & +1.0 & +0.7 \\
\hline
\end{tabular}

The first intermediates (b) and (e) (on figure 9) correspond to one $\mathrm{N}-\mathrm{H}$ cleavage resulting from an $\mathrm{H}$ transfer. If the transfer is made on the closest $\mathrm{O}$ atom forming the peroxo-group (e), the cost is important. The transfer to the second one leads to a situation of much lower energy (b). It also marks a significant progress for the reaction; indeed, the peroxo cleaves and one NO bond is formed. The $\mathrm{O}-\mathrm{NH}_{2}$ - species is adsorbed by two bonds as already found on vanadium oxides (figure $6 \mathrm{c}$ in [153]).

From this first intermediate (b), the postulated second intermediates can result either from an intramolecular $\mathrm{H}$ transfer within the $\mathrm{O}-\mathrm{NH}_{2}$ - moiety (f) or by an $\mathrm{H}$ transfer to the $\mathrm{OH}$ group (c). The latter is the most reasonable. 
In the next step involving an additional $\mathrm{H}$ transfer, another basic site has to be found. In the present model, there is no other $\mathrm{OH}$ group and the choice is between an intramolecular transfer (j) and a transfer to lattice oxygen (d). Both are not very favorable. The lattice oxygen atoms are indeed stabilized by the Madelung field and poorly reactive. An extra $\mathrm{OH}$ group would be necessary. This conclusion can also be reached independently from the consideration of the stoichiometry of the oxidation reaction. The reaction

$$
5 \mathrm{O}_{2}+4 \mathrm{NH}_{3} \rightarrow 4 \mathrm{NO}+6 \mathrm{H}_{2} \mathrm{O}
$$

may be simplified to

$$
\mathrm{OH}+\mathrm{O}_{2}+\mathrm{NH}_{3} \rightarrow \mathrm{NO}+2 \mathrm{H}_{2} \mathrm{O}
$$

that respects the oxidation numbers. It is clear from this equation that an $\mathrm{OH}$ should be present, participating to the redox mechanism.

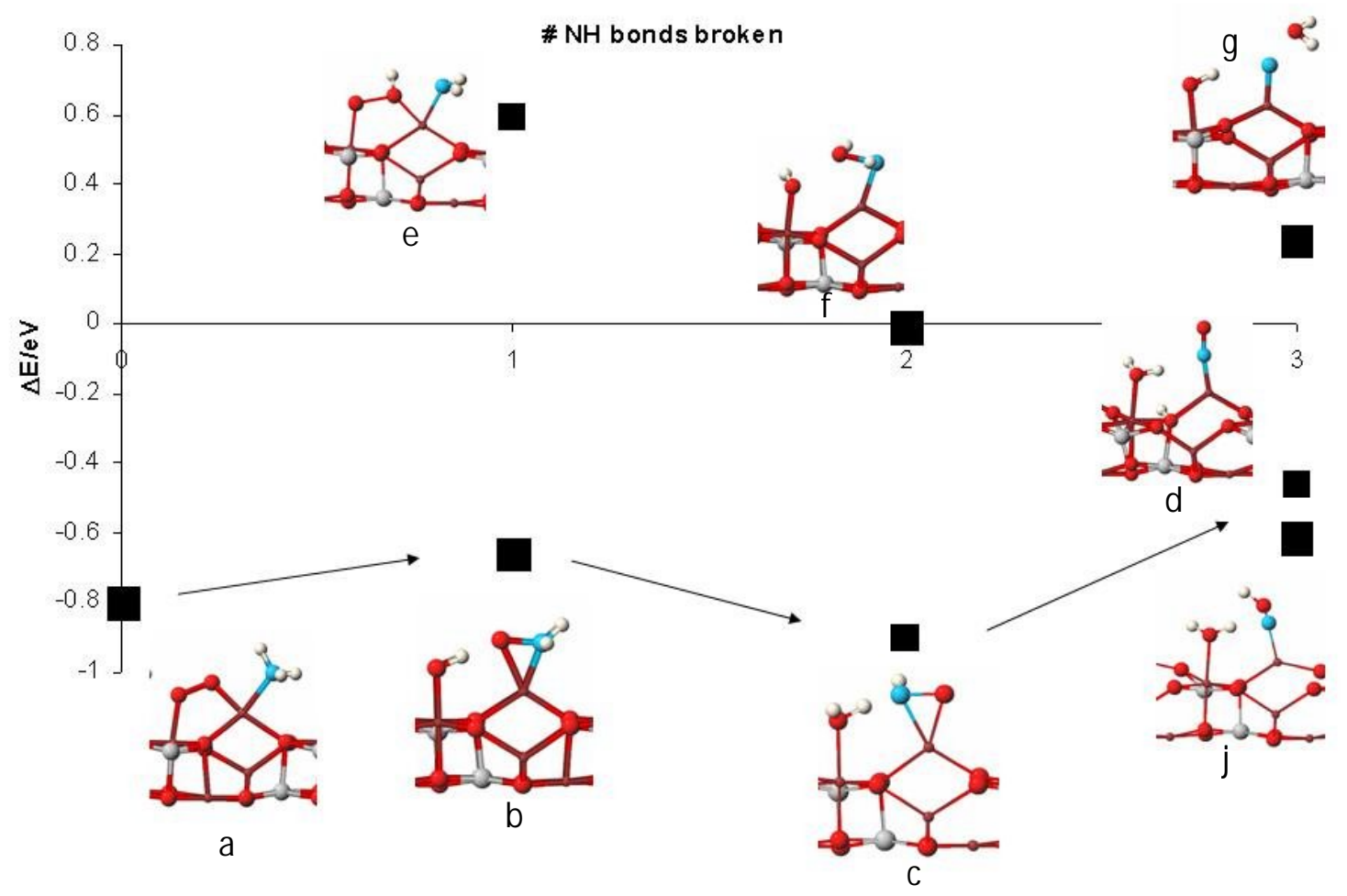

Figure 9: Different intermediates in the $\mathrm{NH}_{3}+\mathrm{O}_{2}$ reaction. The line of zero energy corresponds to the addition of the adsorption energies of $\mathrm{NH}_{3}$ and $\mathrm{O}_{2}$ (no co-adsorption effect). 
In summary, strong co-adsorption effects, cooperative effect being $0.80 \mathrm{eV}$. A structure with $\mathrm{NH}_{3}$ dissociation (NHO), is the lowest in energy (equivalent to $\mathrm{N}_{2} \mathrm{O}+\mathrm{H}_{2} \mathrm{O}$ formation). Cooperative effects more favorable on the $\mathrm{Co}_{2} \mathrm{AlO}_{4}$ surface than on the $\mathrm{CoAl}_{2} \mathrm{O}_{4}$ surface.

\section{The co-adsorption of $\mathrm{NH}_{3}$ and $\mathrm{NO}$ over $\mathrm{Co}_{2} \mathrm{AlO}_{4}$; formation of $\mathrm{N}_{2}$}

The comparison of the thermodynamics of $\mathrm{NH}_{3}$ oxidation to $\mathrm{N}_{2}$ is depicted in figure 10 by comparison with that for $\mathrm{NH}_{3}$ oxidation to $\mathrm{NO}$.

The co-adsorption of $\mathrm{NH}_{3}$ and $\mathrm{NO}$ is less favorable (by $0.95 \mathrm{eV}$ ) than the sum of individual adsorptions. The NO does not bridge two cations, but remains attached to Co $T_{d}$ only. The N$\mathrm{N}$ bond is made only after the breaking of the second $\mathrm{N}-\mathrm{H}$ bond. The first intermediate is high in energy. Contrary to NO the NHO compound occupies a bridging situation by forming an $\mathrm{O}-\mathrm{Al}$ bond; the $\mathrm{H}$ atom is then attached to the $\mathrm{N}$ that is the atom adjacent to the $\mathrm{NH}_{2}$ group. The structure where the $\mathrm{H}$ atom is transferred to the $\mathrm{O}$ atom is $0.51 \mathrm{eV}$ higher in energy. As for the $\mathrm{O}_{2}$ co-adsorption, this structure would mark a progress toward the $\mathrm{N}_{2}$ formation, with the formation of an N-N bond and the cleavage of the N-O bond. The high energy value that is calculated signifies that this path is unlikely.

The total gain of energy for the formation of $\mathrm{N}_{2}$ is very pronounced after the first intermediate (see the rapidly descending curve in figure 10). It is governed by the thermodynamics of the $\mathrm{N}_{2}$ formation that is strongly exothermic. Let us note however that the cooperative effect remains negative for the three first intermediates (the energies are above the reference line in figure 10). Only the last and final step represents a gain in energy relative to the simple adsorption (first intermediate); 


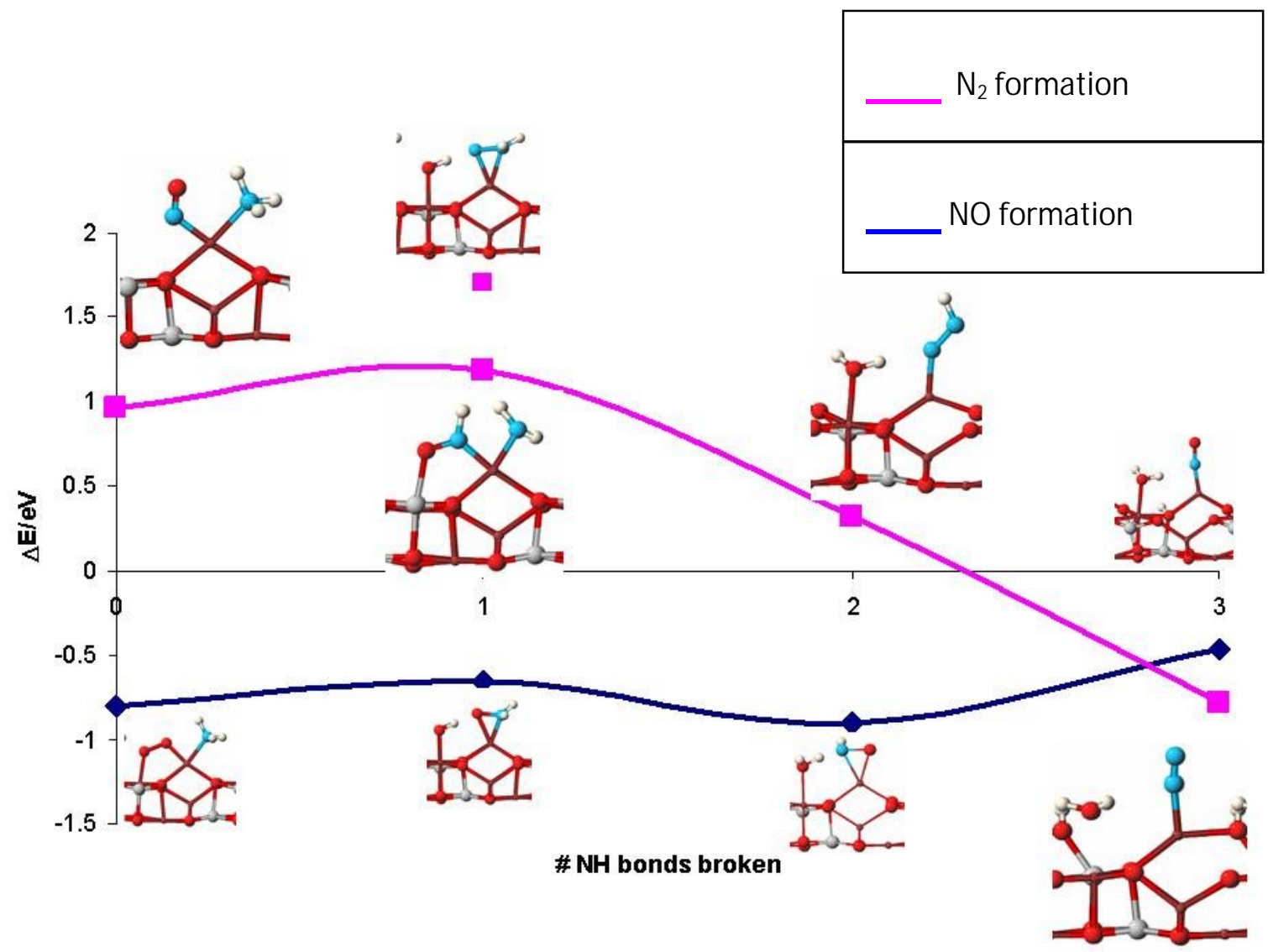

Figure 10: Different intermediates in the $\mathrm{NH}_{3}+\mathrm{NO}$ reaction, compared to the $\mathrm{NH}_{3}+\mathrm{O}_{2}$ reaction. The line of zero energy corresponds to the addition of the individual adsorption energies (no co-adsorption effect).

The formation of $\mathrm{N}_{2}(-0.91 \mathrm{eV})$ is two times more favorable than the formation of NO ($0.46 \mathrm{eV}$ ), however this result only appears at the very end of the reaction path, whereas the formation of $\mathrm{HNO}$ is thermodynamically favorable and favored by cooperative effects at the early stage of the reaction path. In summary, the main adsorption site is the Co $T_{d}$ site; for $\mathrm{CoAl}_{2} \mathrm{O}_{4}$, they are pointing out of the surface and easily accessible. The adsorption trend on the spinels considered for the reactants $\left(\mathrm{NH}_{3}, \mathrm{O}_{2}\right.$ and $\left.\mathrm{NO}\right)$ is $\mathrm{CoAl}_{2} \mathrm{O}_{4}>\mathrm{Co}_{3} \mathrm{O}_{4}>\mathrm{Co}_{2} \mathrm{AlO}_{4}>$ CoO. $\mathrm{CoAl}_{2} \mathrm{O}_{4}$ is expected to be the best catalyst (most selective), having intermediate heat of adsorption for $\mathrm{O}_{2}$ and having a relatively low affinity for $\mathrm{NO} . \mathrm{NH}_{3}$ adsorption is strongly modified by the co-adsorption (site, mode and strength). It is found to dissociate only in the presence of oxygen. No adsorption has been found involving surface oxygens; thus, the 
reaction would not follow a Mars van Krevelen mechanism. A species resulting from $\mathrm{NH}_{3}$ dissociation, the nitroxyl group ( $\mathrm{NHO}$ ), is the lowest in energy in the $\mathrm{NH}_{3}+\mathrm{O}_{2}$ reaction. On the basis of the thermodynamics, the first N-H cleavage is the rate-determining step in ammonia oxidation. It is predicted from these results that the reaction should occur in excess of $\mathrm{O}_{2}$ in order to avoid the formation of $\mathrm{N}_{2} \mathrm{O}$ or $\mathrm{N}_{2}$.

\section{Conclusions}

After an introduction drawing the scope of the special issue dedicated to Prof. Vedrine on nanocatalysis science, results on spinel nano-materials considering a collection of techniques are presented, which is considered today, a state-of the-art in the field of catalyst research (characterization and study of structure/reactivity relationship). Through a selected collection of techniques, experimental as well as theoretical, this setup of techniques on the characterization of spinels $\left(\mathrm{ZnAl}_{2} \mathrm{O}_{4}\right)$ through XAS and by wide angle anomalous X-ray scattering (AWAXS) is illustrated. The access to beamtime on different synchrotron centres as well as the technical developments of optics and detection makes combined XAS and AWAXS more and more accessible and is expected to have a bright future in the field of catalyst characterization [154-162]. On the theoretical/computational DFT electronic structure have been performed and are expected to be provide new insights, especially when combined with X-ray absorption experiments. Subsequently, the effect of $\mathrm{Al} / \mathrm{Zn}$ substitution was investigated. In the last part, a DFT study on related $\mathrm{Co} / \mathrm{Al}$ spinels is presented. $\mathrm{Co} / \mathrm{Al}$ spinel surfaces are described and their reactivity towards $\mathrm{NO}, \mathrm{O}_{2}$, and $\mathrm{NH}_{3}$ explored. Possible reaction paths are presented for the $\mathrm{NH}_{3}+$ oxygen and NO. These very first results are the basis for future transition state calculations, which will enable to determine completely the thermodynamics and kinetics of the NO formation from ammonium over this type of catalysts.

\section{Acknowledgements}

This work was performed using HPC resources from the CCRE of Université Pierre et Marie Curie. F.T. acknowledges Prof. C. Minot and Dr. M. Calatayud for fruitful discussions. 


\section{References}

[1] G. Ertl, Nobel Lecture 12/8/2007.

[2] W. Ostwald, Phys. Z. 3 (1902) 313-322.

[3] W. Ostwald, Ann. Naturphil. 9 (1910) 1-10.

[4] P. Sabatier, La catalyse en chimie organique, Translated from French to American by E.E. Reid, 2nd printing in 1923, Paris et Liège/NewYork, 1913, p.

[5] J. C. Vedrine, G. Coudurier, M. Forissier, J. C. Volta, Catalysis Today 1 (1987) 261-280.

[6] J. C. Vedrine, Applied Catalysis A : General 474 (2014) 40-50.

[7] J. M. M. Millet, M. Forissier, D. Rouzies, P. Bonnet and J. C. Vedrine, Role of water on the properties of $\mathrm{FePO}$ catalysts used for the oxidative dehydrogenation of isobutyric acid, 1996, p. 1011-1020.

[8] J. C. Vedrine, G. Coudurier, J. M. M. Millet, Catalysis Today 33 (1997) 3-13.

[9] M. Che and J. C. Védrine, Characterization of Solid Materials and Heterogeneous Catalysts: From Structure to Surface Reactivity, Ed. Wiley-VCH, 2012

[10] F. Tielens, M. Calatayud, Catalysis Today 177 (2011)1-2.

[11] M. T. Sananes, A. Tuel, J. C. Volta, J. of Catalysis 145 (1994) 251-255.

[12] I. Fechete, Y. Wang, J. C. Vedrine, Catalysis Today 189 (2012) 2-27.

[13] F. Garin, Applied Catalysis A General 222 (2001) 183-219.

[14] F. Tielens, C. Minot, Surface Science 600 (2006) 357-365.

[15] M. M. Islam, D. Costa, M. Calatayud, F. Tielens, J. of Physical Chemistry C 113 (2009) 10740-10746.

[16] A. Wojtaszek, I. Sobczak, M. Ziolek, F. Tielens, J. of Physical Chemistry C 113 (2009) 13855-13859.

[17] A. E. Lewandowska, M. A. Banares, F. Tielens, M. Che, S. Dzwigaj, J. of Physical Chemistry C 114 (2010) 19771-19776.

[18] F. Tielens, S. Dzwigaj, Catalysis Today 152 (2010) 66-69.

[19] H. Guesmi, F. Tielens, J. of Physical Chemistry C 116 (2012) 994-1001

[20] J. Handzlik, R. Grybos, F. Tielens, J. of Physical Chemistry C 117 (2013) 8138-8149.

[21] A. R. Almeida, M. Calatayud, F. Tielens, J. A. Moulijn, G. Mul, J. of Physical Chemistry C 115 (2011) 14164-14172.

[22] A. E. Lewandowska, M. Calatayud, F. Tielens, M. A. Banares, J. of Physical Chemistry C 115 (2011) 24133-24142.

[23] A. E. Lewandowska, M. Calatayud, F. Tielens, M. A. Banares, J. of Physical Chemistry C 117 (2013) 25535-25544.

[24] M. Calatayud, F. Tielens, F. De Proft, Chem. Phys. Lett. 456 (2008) 59-63.

[25] F. Tielens, C. Gervais, J. F. Lambert, F. Mauri, D. Costa, Chemistry of Materials 20 (2008) 3336-3344.

[26] A. Tougerti, C. Methivier, S. Cristol, F. Tielens, M. Che, X. Carrier, Physical Chemistry Chemical Physics 13 (2011) 6531-6543.

[27] F. Tielens, W. Langenaeker, P. Geerlings, J. of Molecular Structure-Theochem 496 (2000) 153-162.

[28] N. Raveendran Shiju, V.V. Guliants, Applied Catalysis A: General 356 (2009)1-17.

[29] F.F. Tao, Chem. Commun. 48 (2012) 3812-3814.

[30] S. Bordiga, E. Groppo, G. Agostini, J. A. van Bokhoven, C. Lamberti, Chemical Reviews 113 (2013) 1736-1850.

[31] G. Jacobs, W. Ma, P. Gao, B. Todic, T. Bhatelia, D.B. Bukur, B.H. Davis, Cat. Today 214 (2013)100-139. 
[32] J. A. Rodriguez, J. C. Hanson, P. J. Chupas, In-situ Characterization of Heterogeneous Catalysts, Wiley, New York, Berlin, 2013.

[33] D. Bazin, Comptes Rendus Chimie, 17 (2014) 615-624.

[34] C. Garino, E. Borfecchia, R. Gobetto, J.A. van Bokhoven, C. Lamberti, Coordination Chemistry Reviews, 277-278 (2014) 130-186.

[35] C. Li, Y. Bando, M. Nakamura, N. Kimizuka, H. Kito, Materials Research Bulletin 35 (2000) 351-358.

[36] M.W. Small, S.I. Sanchez, L.D. Menard, J.H. Kang, A.I. Frenkel, R.G. Nuzzo, J. Am. Chem. Soc. 133 (2011) 3582-3591.

[37] N. Chakroune, G. Viau, S. Ammar, L. Poul, D. Veautier, M.M. Chehimi, C. Mangeney, F. Villain, F. Fiévet, Langmuir 21 (2005) 6788-6796.

[38] Z. Zhou, Y. Zhang, Z. Wang, W. Wei, W. Tanga, J. Shia, R. Xiong, Applied Surface Science 254 (2008) 6972-6975.

[39] D.E. Sayers, E.A. Stern, F.W. Lytle, Phys. Rev. Lett. 27 (1971) 1204-1207.

[40] F.W. Lytle, D.E. Sayers, E.A. Stern, Phys. Rev B 11 (1975) 4825- 4835.

[41] D. Bazin, L. Guczi, App. Cat. A 213 (2001) 147-162.

[42] S. Carenco, A. Tuxen, M. Chintapalli, E. Pach, C. Escudero, T.D. Ewers, P. Jiang, F. Borondics, G. Thornton, P. Alivisatos, H. Bluhm, J. Guo, M. Salmeron, J. Phys. Chem. C 117 (2013) 6259 - 6266.

[43] D. Bazin, J. Lynch, M. Ramos-Fernandez, Oil Gas Sci. Technol., Rev. IFP 58 (2003) 667- 683.

[44] J. H. Sinfelt, G. H. Via, F. W. Lytle, Catalysis Reviews: Science and Engineering 26 (1984) $81-140$.

[45] X-ray Absorption Fine Structure for Catalysts and Surfaces, in: Y. Iwasawa (Ed.), World Scientific, 1996.

[46] L. Guczi, D. Bazin, App. Cat. A 188 (1999)163-174.

[47] D. Bazin, C. Mottet, G. Treglia, App. Cat. A 200 (2000) 47-54.

[48] Nanotechnology in Catalysis, B. Zhou, S. Hermans, G.A. Somorjai (Editors) 2003

[49] D. Bazin, J.J. Rehr, J. of Physical Chemistry B 107 (2003) 12398-12402.

[50] J.-D. Grunwaldt, M. Caravati, S. Hannemann, A. Baiker, Phys. Chem. Chem. Phys. 6 (2004) 3037-3047.

[51] A. A. Veligzhanin, Ya.V. Zubavichus, A. A. Chernyshov, A. L. Trigub, A. S. Khlebnikov, A. I. Nizovskii, A. K. Khudorozhkov, I. É. Beck, V. I. Bukhtiyarov, J. of Structural Chemistry 51 (2010)20-27.

[52] H.J. Fan, M. Knez, R. Scholz, K. Nielsch, E. Pippel, D. Hesse, M. Zacharias, U. Gösele Nature Mat. 5(2006) 627-631.

[53] R. Ferrando, J. Jellinek, R.L. Johnston, Chem. Rev. 108 (2008) 845-910.

[54] D. Carta, M. F. Casula, A. Falqui, D. Loche, G. Mountjoy, C. Sangregorio, A. Corrias J. Phys. Chem. C 113 (2009) 8606-8615.

[55] S. Gomes, J.-M. Nedelec, E. Jallot, D. Sheptyakov, G. Renaudin, Chem. Mater. 23 (2011)3072-3085.

[56] S. Pin, M.A. Newton, F. D’Acapito, M. Zema, S.C. Tarantino, G. Spinolo, R.A. De Souza, M. Martin, P. Ghigna, J. Phys. Chem. C 116 (2012) 980-986.

[57] D. Bazin, M. Daudon, C. Combes, C. Rey, Chem. Rev. 112 (2012)5092-5120

[58] U. Wongpratat, S. Meansiri, E. Swatsitang, Microelectronic Engineering 126 (2014) 19-26.

[59] N.S. Marinkovic, Q. Wang, L. Barrio, S.N. Ehrlich, S. Khalid, C. Cooper, A.I. Frenkel, NIM A 649 (2011) 204-206.

[60] D. Ferri, M.S. Kumar, R. Wirz, A. Eyssler, O. Korsak, P. Hug, A. Weidenkaff, M.A. Newton, Phys. Chem. Chem. Phys. 12(2010)5634-5646. 
[61] J.-D. Grunwaldt, N. van Vegten, A. Baiker, W. van Beek, J. Phys.: Conf. Ser. 190 (2009) 012160.

[62] A. Patlolla, E. V. Carino, S. N. Ehrlich, E. Stavitski, A. I. Frenkel ACS Catalysis 2 (2012) 2216-2223

[63] A. M. Beale, M. J. van der Eerden, K. Kervinen, M. A. Newton, B. M. Weckhuysen Chem. Commun. (2005) 3015-3017.

[64] M. A. Newton, A.J. Dent, S.G. Fiddy, B. Jyoti, J. Evans, Catalysis Today 126 (2007) 64-72.

[65] S. Schneider, D. Bazin, G. Meunier, R. Noirot, M. Capelle, F. Garin, G. Maire, Catalysis Letters 71 (2001)155-162.

[66] D. Bazin, I. Kovács, J. Lynch, L. Guczi, Applied Catalysis A: General 242 (2003) 179-186

[67] C. Pichon, H. Palancher, J. L. Hodeau, J. F. Bérar, Oil \& Gas Science and Technology - Rev. IFP 60 (2005) 831-848.

[68] D. Bazin, D. Guillaume, Ch. Pichon, D. Uzio, S. Lopez, Oil \& Gas Science and Technology - Rev. IFP 60 (2005) 801-813

[69] S.M. Oxford, P.L. Lee, P.J. Chupas, K.W. Chapman, M.C. Kung, H.H. Kung, J. Phys. Chem. C 114 (2010) 17085-17091.

[70] S.A. Jimenez-Lam, M.G. Cardenas-Galindo, B.E. Handy, S.A. Gomez, G.A. Fuentes, J.C. Fierro-Gonzalez, J. Phys. Chem. C 115 (2011) 23519-23526.

[71] A. I. Frenkel, Q. Wang, N. Marinkovic, J. G. Chen, L. Barrio, R. Si, A. López Cámara, A. M. Estrella, J. A. Rodriguez, J. C. Hanson, J. of Physical Chemistry C 115 (2011) 17884-17890.

[72] J. A. Gomes, G. M. Azevedo, J. Depeyrot, J. Mestnik-Filho, F. L. O. Paula, F. A. Tourinho,R. Perzynski, J. Phys. Chem. C 116 (2012) 24281-24291.

[73] M. Filez, E.A. Redekop, H. Poelman, V.V. Galvita, R.K. Ramachandran, J. Dendooven, Ch. Detavernier, G.B. Marin, Chem. Mater. 26 (2014)5936-5949.

[74] C. Yin, F. Zheng, S. Lee, J. Guo, W.-C. Wang, G. Kwon, V. Vajda, H.-H. Wang, B. Lee, J. DeBartolo, S. Seifert, R.E. Winans, S. Vajda, J. Phys. Chem. A 118 (2014)8477-8484.

[75] A.R. Morris, M.D. Skoglund, J.H. Holles, Applied Catalysis A: General 489 (2015) 98-110.

[76] D.J. Childers, N.M. Schweitzer, S.M. Kamali Shahari, R.M. Rioux, J.T. Miller, R.J. Meyer, J. of Catalysis 318 (2014) 75-84.

[77] F. Cai, S. Shan, L. Yang, B. Chen, J. Luo, C.-J Zhong, Science China Chemistry in press

[78] A.M. Beale, G. Sankar, Chem. Mat. 18 (2006) 263 - 272.

[79] R. Revel, D. Bazin, P. Parent, C. Laffon, Cat. Let. 74(2001)189-192.

[80] N.S. Guyot-Sionnest, F. Villain, D. Bazin, H. Dexpert, F. Lepeltier, J. Lynch, J.P. Bournonville, Cat. Let. 8 (1991) 283-296.

[81] N.S. Guyot-Sionnest, F. Villain, D. Bazin, H. Dexpert,F. Lepeltier, J. Lynch, Cat. Let. 8 (1991) 297-304.

[82] A. Rochet, V. Moizan, C. Pichon, F. Diehl, A. Berliet, V. Briois, Catal. Today 171 (2011) 186-191.

[83] C. La Fontaine, L. Barthe, A. Rochet, V. Briois, Catal. Today 20 (2013) 148-158.

[84] Q. Kong, F. Baudelet, J. Han, S. Chagnot, L. Barthe, J. Headspith, R. Goldsbrough, F.E. Picca, O. Spalla, Scientific Rep. 2 (2013) 1018 - 1027.

[85] G. Ouvrard, M. Zerrouki, P. Soudan, B. Lestriez, Ch. Masquelier, M. Morcrette, S. Hamelet, S. Belin, A.M. Flank, F. Baudelet, J. Power Sources 229 (2013) 16 -21. 
[86] J. Moonen, J. Slot, L. Lefferts, D. Bazin, H. Dexpert, Physica B 208\&209 (1995) 689-690.

[87] S. Cammelli, D. Lützenkirchen-Hecht, C. Degueldre, J Bertsch, R Frahm, J. Phys.: Conf. Ser. 190 (2009) 012027.

[88] F. Thibault-Starzyk, E. Seguin, S. Thomas, M. Daturi, H. Arnaolds, D.A. King, Science 324 (2009) 1048-1051.

[89] G.N. Greaves, P.J. Durham, G. Diakun, P. Quinn, Nature 294 (1981) 139 - 142.

[90] D. Bazin, D. Sayers, J.J. Rehr, C. Mottet, J. Phys. Chem. B. 101 (1997) 5332 - 5336.

[91] F. Tielens, M. Calatayud, Catalysis Today 177 (2011) 1-2.

[92] D. Park, Introduction to the quantum theory; McGraw-Hill: New-York, 1974.

[93] Friedel J 1978 Physics of Metals (Cambridge: Cambridge University Press)

[94] J. Friedel, Surf. Sci. 106 (1981) 582-583.

[95] F.D. Vila, J.J. Rehr, S.D. Kelly, S.R. Bare, J. of Physical Chemistry C 117 (2013) 12446-12457.

[96] L.S. Sarma, H.-L. Chou, M.-Y. Cheng, F. Taufany, F.-J. Lai, M.-C. Tsai, S.-H. Chang, B.-J. Hwang, in Nanotechnologies for the Life Sciences 2007 Wiley-VCH Verlag GmbH \& Co. KGaA.

[97] X. Wang, N. Li, L.D. Pfefferle, G.L. Haller, J. of Physical Chemistry C 114 (2010)16996-17002

[98] Y. Cauchois, N.F. Mott, Phil. Mag. 40 (1949) 1260-1270.

[99] D. Bazin, J. Rehr, Catal. Lett. 87 (2003) 85 -90.

[100] D. Bazin, M. Daudon, J. Phys. D: Appl. Phys. 45 (2012) 383001.

[101] D. Bazin, J. Rehr, J. Phys. Chem. C 115 (2011) 23233 - 23236.

[102] D.L. Ge, Y.J. Fan, C.L. Qi, Z.X. Sun J. of Material Chemistry A 1(2013) 1651-1658.

[103] M.Y. Lavrentiev, J.A. Purton, N.L. Allan, Am. Min. 88 (2003) 1522-1531.

[104] P. Mierczynski, R. Ciesielski, A. Kedziora, M. Zaborowski, W. Maniukiewicz, M. Nowosielska, M. I. Szynkowska, T.P. Maniecki, Cat. Let. 144 (2014) 723-735.

[105] J.J. Rehr, A.L. Ankudinov, Coord. Chem. Rev. 249 (2005) 131 - 140.

[106] J.J. Rehr, R.C. Albers, Phys. Rev. B 41 (1990) 8139 - 8149.

[107] M.W. Tew, J.T. Miller, J.A. van Bokhoven, J. Phys. Chem. C 113 (2009)15140-15147.

[108] S. Chen, Y. Wu, P. Cui, W. Chu, X. Chen, Z. Wu, J. of Physical Chemistry C 117 (2013) 25019-25025.

[109] V. Krishnan, R.K. Selvan, C.O. Augustin, A. Gedanken, H. Bertagnolli, J. Phys. Chem. C 111 (2007) 16724-16733.

[110] N. Yu. Safontseva, I. Ya. Nikiforov, Physics of the Solid State 42 (2000) 1427-1430.

[111] D.R. Neuville, D. de Ligny, L. Cormier, G.S. Hendersond, J. Roux, A.-M. Flank, P. Lagarde, Geochimica et Cosmochimica Acta 73 (2009) 3410-3422.

[112] S. J. A. Figueroa, S. J. Stewart, J. Synchrotron Rad. 16 (2009) 63-68.

[113] S. Nakashima, K. Fujita, K. Tanaka, K. Hirao, T. Yamamoto, I. Tanaka, Phys. Rev. B 75 (2007)174443 - 174452.

[114] J.M. Paque, S.R. Sutton, S. B. Simon, J. R. Beckett, D.S. Burnett, L. Grossman, H. Yurimoto, S. Itoh, H.C. Connolly, Meteoritics and Planetary Science 48 (2013)2015-2043.

[115] T. Jermwongratanachai, G. Jacobs, W.D. Shafer, W . Ma, V.R. Rao Pendyala, B.H. Davis, B. Bitiyanan, S. Khalid, D.C. Cronauer, A. J. Kropf, Ch.L. Marshall, Top. Catal. 57 (2014)479-490.

[116] C. Pirola, M. Scavini, F. Galli, S. Vitali, A. Comazzi, F. Manenti, P. Ghigna Fuel 132(2014) 62-70. 
[117] A. Griboval-Constant, A. Butel, V.V. Ordomsky, P.A. Chernavskii, A.Y. Khodakov Applied Catalysis A: General 481(2014)116-126.

[118] N.E. Tsakoumis, M. Rønning, Ø. Borg, E. Rytter, A. Holmen, Catalysis Today 154 (2010) 162-182.

[119] A.Y. Khodakov Catalysis Today, 144 ( 2009) 251-257.

[120] G. Jacobs, W. Ma, P. Gao, B. Todic, T. Bhatelia, D.B. Bukur, B.H. Davis, Catalysis Today 214 (2013) 100-139.

[121] A.Yu. Khodakov, J. Lynch, D. Bazin, B. Rebours, N. Zanier, B. Moisson, P. Chaumette, J. of Catalysis 168 (1997) 16-25.

[122] D. Bazin, L. Borko, Zs. Koppany, I. Kovacs, G. Stefler, L.I. Sajo, Z. Schay, L. Giczi, Cat. Let. 84 (2002)169-182.

[123] L. Guczi, D. Bazin, I. Kovacs, L. Borko, Z. Schay, J. Lynch, P. Parent, C. Lafon, G. Stefler, Zs. Koppany, I. Sajo, Topics in Catalysis 20 (2002) 129 -139.

[124] J. Hong, E. Marceau,A.Y. Khodakov, A. Griboval-Constant, C. La Fontaine,V. Briois Chem. Eur. J. 18 (2012) 2802 - 2805.

[125] A. Longo, L. Sciortino, F. Giannici, A. Martorana, J. App. Crys. 47 (2014)1562-1568.

[126] R. Revel, D. Bazin, E. Elkaim, Y. Kihn, and H. Dexpert, J. Phys. Chem. B 104 (2000) 9828-9835.

[127] M.G. Samant, G. Bergeret, G. Meitzner, P. Gallezot, M. Boudart, J. Phys. Chem. 86 (1988) 3542-3546.

[128] M.G. Samant, G. Bergeret, G. Meitzner, P. Gallezot, M. Boudart, J. Phys. Chem. 86 (1988) 3547-3554.

[129] O. Ducreux, B. Rebours, J. Lynch, M. Roy-Auberger, D. Bazin, Oil \& Gas Science And Technology - Rev. IFP, 64 (2009) 49-62.

[130] Q. Ma, J.-F. Lee, D.E. Sayers, Physica B: Condensed Matter, 208-209 (1995) 663-664.

[131] Guinier, A. Théorie et technique de la radiocristallographie; Dunod: Paris, 1964.

[132] D.C. Bazin, D.A. Sayers, Jpn. J. Appl. Phys. 32 (1993) 249-251.

[133] D.C. Bazin, D.A. Sayers, Jpn. J. Appl. Phys. 32 (1993) 252-253.

[134] Waseda, Y. Novel Application of anomalous (resonance) X-ray scattering for Structural characterization of disordered material; Springer-Verlag: Berlin.

[135] D. Bazin, L. Guczi, J. Lynch, App. Cat. A 226 (2002) 87-113.

[136] J. L. Hodeau, H. Renevier, in Neutron and X-ray Spectroscopy Ed. F. Hippert, E. Geissler, J.L. Hodeau, E. Lelièvre-Berna, J.-R. Regnard, Springer, 2006.

[137] A. N. Shmakov, J. of Structural Chemistry 53 (2012) 133-149.

[138] J.R. Gallagher, T. Li, H. Zhao, J. Liu, Y. Lei, X. Zhang, Y. Ren, J.W. Elam, R.J. Meyer, R.E. Winans, J.T. Miller, Catal. Sci. Technol., 4 (2014) 3053-3063.

[139] D.T. Cromer, J.B. Mann, Acta Crystallogr. A 24 (1968) 321 - 324.

[140] S. Sasaki, KEK Report 83-82; National Laboratory for High Energy Physics: Tsukuba, Japan, 1983.

[141] R. Schlögl, Advances in Cat. 52 (2009) 273-338.

[142] S.V. Tsybulya, D.A. Yatsenko, J. of Structural Chemistry 53 (2012) S150-S165.

[143] E.M. Moroz, Theoretical and experimental chemistry 49 (2013)71-87.

[144] P. Debye, Ann. Physik. 351 (1915) 809-823.

[145] U.S. Jeng, Y.H. Lai, H.S. Sheu, J.F. Lee, Y.S. Sun, W.T. Chuang, Y.S. Huang, D.G. Liu, J. App. Cryst. 40 (2007) S418-S422.

[146] V. A. Sadykov, L. A. Isupova, I. A. Zolotarskii, L. N. Bobrova, A. S. Noskov, V. N. Parmon, E. A. Brushtein, T. V. Telyatnikova, V. I. Chernyshev, V. V. Lunin, Applied Catalysis A : General 204 (2000) 59-87. 
[147] G. Kresse, J. Furthmuller, Computational Materials Science 6 (1996) 15-50

[148] G. Kresse, J. Hafner, Physical Review B 49 (1994) 14251-14269.

[149] J. P. Perdew, J. A. Chevary, S. H. Vosko, K. A. Jackson, M. R. Pederson, D. J. Singh C. Fiolhais, Physical Review B 46 (1992) 6671-6687.

[150] J. P. Perdew, Y. Wang, Physical Review B 45 (1992) 13244-13249.

[151] P. Broqvist, I. Panas, H. Persson, J. of Catalysis 210 (2002) 198-206.

[152] V. A. Sadykov, L. A. Isupova, I. A. Zolotarskii, L. N. Bobrova, A. S. Noskov, V. N. Parmon, E. A. Brushtein, T. V. Telyatnikova, V. I. Chernyshev, V. V. Lunin, Applied Catalysis A General 204 (2000) 59-87.

[153] M. Calatayud, B. Mguig, C. Minot, Surface Science Reports 55 (2004) 169-236.

[154] D. Bazin, Topics in Catalysis 18 (2002)79 - 84.

[155] A.E. Russell, A. Rose, Chem. Rev. 104 (2004)4613-4636.

[156] J.-D. Grunwaldt, M. Caravati, S. Hannemann, A. Baiker Phys. Chem. Chem. Phys. 6 (2004) 3037-3047

[157] A.Y. Khodakov, W. Chu, P. Fongarland Chem. Rev. 107 (2007)1692 - 1744.

[158] G. Jacobs, B. H. Davis, Catalysis 20 (2007) 122-285.

[159] R. Ferrando, J. Jellinek, R.L. Johnston, Chem. Rev. 108 (2008) 845 - 910.

[160] M.A. Newton,Chem. Soc. Rev. 37 (2008) 2644-2657.

[161] A.A. Veligzhanin,Ya. V. Zubavichus,A.A. Chernyshov,A.L. Trigub, A.S. Khlebnikov,A.I. Nizovskii,A.K. Khudorozhkov,I.É. Beck,V.I. Bukhtiyarov J. of Structural Chemistry 51 (2010)20-27.

[162] N. Koizumi, S. Suzuki, Y. Ibi, Y. Hayasaka, Y. Hamabe, T. Shindo and M. Yamada J. Synchrotron Rad. 19 (2012) 74-83. 


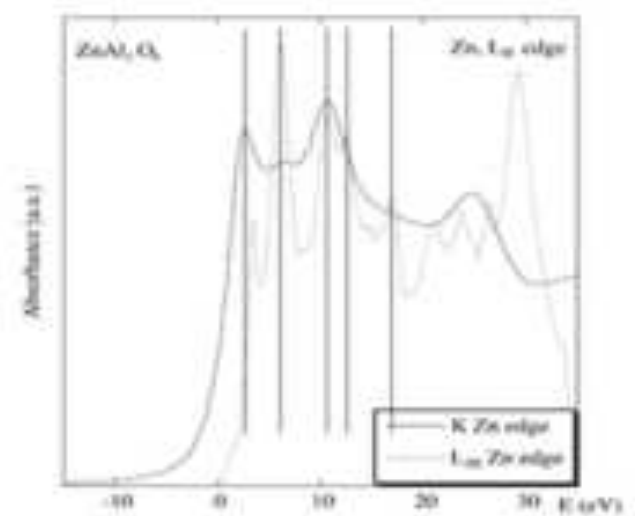

AWAXS XAS
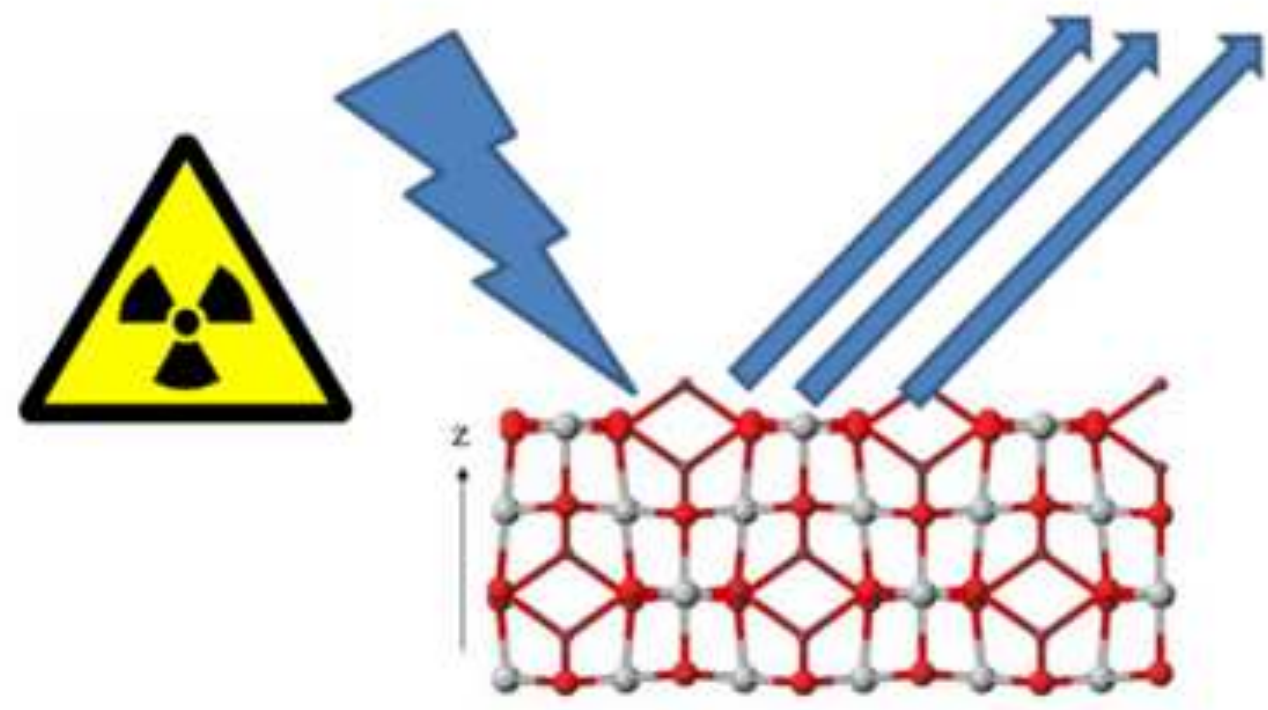

Spinel structure

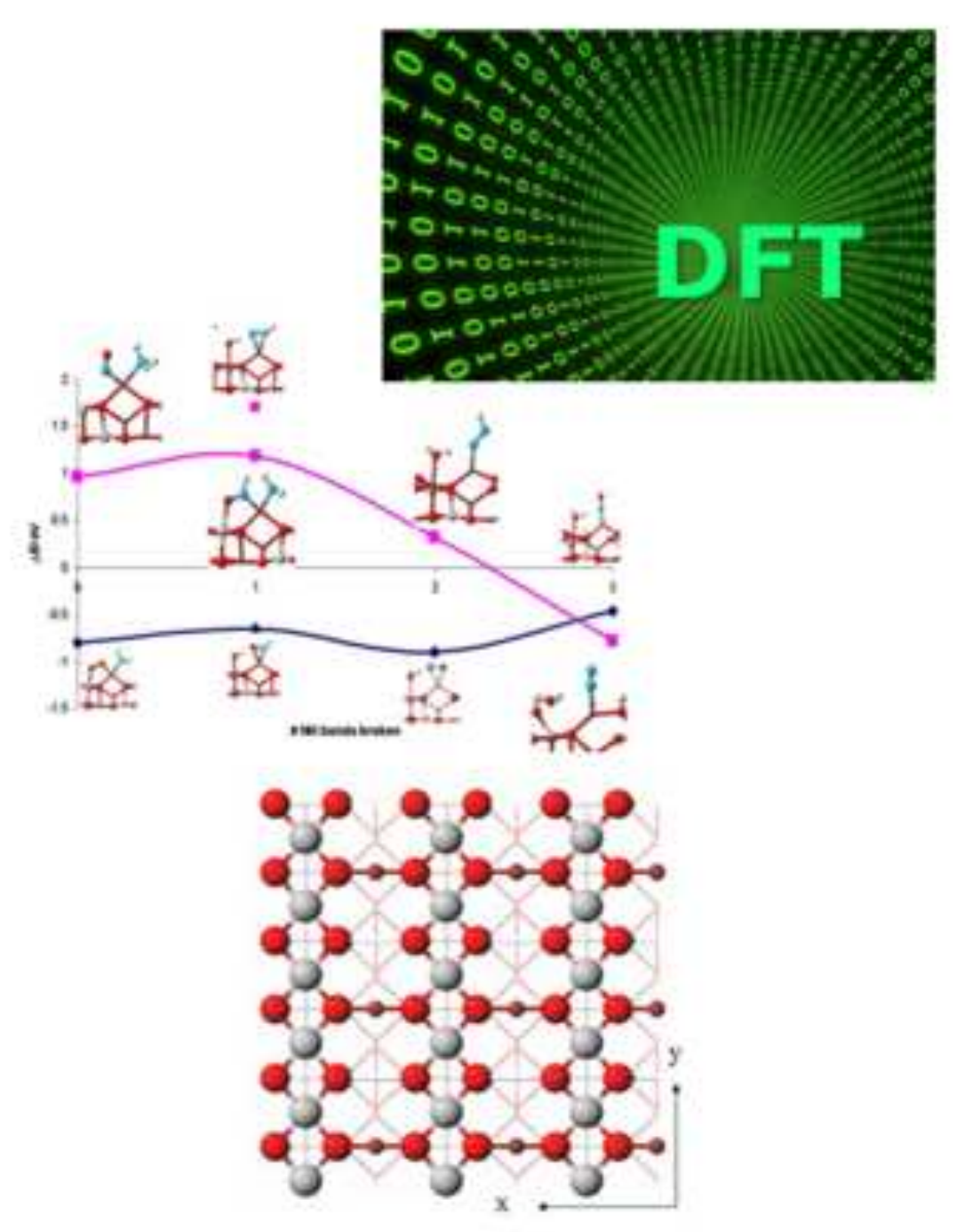

